\title{
The Effect of Traceability System and Managerial Initiative on Indonesian Food Cold Chain Performance: A Covid-19 Pandemic Perspective
}

\author{
Ilyas Masudin $^{1}$ (D) Anggi Ramadhani ${ }^{1} \cdot$ Dian Palupi Restuputri $^{1} \cdot$ Ikhlasul Amallynda $^{1}$
}

Received: 22 March 2021 / Accepted: 10 July 2021 / Published online: 3 August 2021

(C) Global Institute of Flexible Systems Management 2021

\begin{abstract}
This study aims to determine the effect of managerial initiatives on the adoption of traceability systems on food cold chain performance during the Covid-19 pandemic. Managerial initiatives are allegedly needed to improve the company's performance because it improves the traceability system in the supply chain. In addition, the effect of the traceability system adoption on the Indonesian food cold-chain performance during the Covid-19 pandemic is also discussed in this study. This study uses a quantitative approach and purposive sampling with a questionnaire research instrument obtained 250 statements of Indonesian consumers and retail employees. Partial least squares for structural equation modeling (PLS-SEM) were used to analyze latent variables' relationships. This study indicates that the traceability system has a significant effect on the performance of the food cold-chain during the Covid-19 pandemic. In addition, the adoption of electronic data exchange (EDI), radio frequency identification (RFID), and blockchain significantly impacted traceability systems during the Covid-19 pandemic. The managerial application of the initiative showed a positive and significant impact on the performance of the food cold-chain during the Covid-19 pandemic. However, the managerial
\end{abstract}

Ilyas Masudin

masudin@umm.ac.id

Anggi Ramadhani

anggi222ramadhani@gmail.com

Dian Palupi Restuputri

restuputri@umm.ac.id

Ikhlasul Amallynda

ikhlasulamallynda@gmail.com

1 University of Muhammadiyah Malang, Jalan Raya Tlogomas 246, Malang 65144, Indonesia initiative is not able to moderate the adoption of the traceability system.

Keywords Blockchain · EDI .

Food cold chain performance during Covid-19 .

Managerial initiative · RFID - Traceability system

\section{Introduction}

Fulfilling the increase in the supply of cold-chain products requires a good integration to connect all supply chain parties (Lewis \& Boyle, 2017). Food cold-chain management associates all parties in the supply chain, from the farmer to the consumer (Joshi et al., 2011). There is a significant growth in Indonesia's cold-chain market every year and predicting increase from $4-6 \%$ to $8-10 \%$ in the next five years (ILFA, 2020). Furthermore, Indonesia's food and agriculture sector is the most considerable contribution of the cold-chain sector to Indonesia's gross domestic product (GDP) (BPS, 2019). The food cold-chain system helps the expansion of the Indonesian food supply. This system uses a cold chain's temperature control system that can inhibit microbial growth to extends product storage life and maintain nutritional product quality well (Aung \& Chang, 2014a; Carullo et al., 2008; Shashi et al., 2018).

However, the food cold-chain market has become disrupted due to the spread of the Covid-19 pandemic in all of the world caused by Coronavirus (SARS-CoV-2). This is a big challenge for Indonesia's food cold chain industry. An infected worker's droplets could transmit the virus rapidly and become a necessary concern as it causes acute respiratory syndrome (Ganyani et al., 2020; Wiersinga et al., 2020). The government issued several policies to reduce 
the spread of Coronavirus transmission by implementing health protocols to large-scale social restrictions in all aspects of the industry (Paramita et al., 2021; Tam et al., 2021; Ufua et al., 2021; Vergara et al., 2021). This policy impacts the supply and demand, such as food losses cases. The food cold chain product has a short life span characteristic and cannot be recycled (Masudin \& Safitri, 2020). Moreover, the possibility of Coronavirus contamination along the supply chain is another concerning issue related to product safety. The complexity of the problems raises triggers for product-related information traceability systems that can monitor products' condition along the supply chain, considering the fast transmission of viruses.

Optimal integration can evaluate supply chain performance from traceability initiatives and operation management (Wang et al., 2009). The traceability system detects the causes of quality and safety problems by determining their origin and characteristics from the upstream supply chain (Bechini et al., 2005). The utilization of the Internet of Things (IoT) can increase product visibility, such as product information, environmental conditions around the product, and product quality (Tsang et al., 2018). Effective management between corporate governance and employees is needed to affect business performance positively (Galbreath, 2006). Besides, stakeholders' initiative in the food cold-chain is an important factor in successfully implementing the traceability system (Lewis \& Boyle, 2017). Without any initiative to encourage stakeholders, the traceability system performance cannot be optimal. Thus, this study was conducted to determine the influence of managerial initiative on traceability system adoption. The traceability system's effect on the Indonesian food cold chain performance during the Covid-19 pandemic was determined in this study.

The structure of this article is written in six sections. The first section (introduction) discusses this study's background and identifies the gap between previous studies and the research statement. Section two discusses the related studies that contributed to developing the framework. Subsequently, the following section discusses the research methodology, followed by Section four, which discusses the results and discussion. Section five presents the managerial implications, and it is followed by the final section, which is the conclusion and limitations.

\section{Literature Review}

\section{Food Cold Chain Performance}

The cooling system is applied in the post-harvest and after food processing. This system uses the proper temperature settings to keep product quality in good condition (Bogataj et al., 2005; Shabani et al., 2015; Shashi et al., 2018). Temperature control errors can occur before and after loading and unloading in warehouses or consumer refrigerators' storage (Mercier et al., 2017). These errors lead to potential damage to the cold-chain product. Product classification in the food cold-chain is shown in Fig. 1.

The structural resistance of different foodstuffs makes the distinction between products. Fresh food products such as vegetables and fruit can keep up to two months in chilled rooms with low temperatures $\left(1-7^{\circ} \mathrm{C}\right)$. Meanwhile, processed products, canned food, and animal protein require a freezer at room temperature below $0{ }^{\circ} \mathrm{C}$ (Capricorn Indonesia Consult, 2019). Many aspects of cold chain performance, such as product shelf life, production time, production period, physical product properties, type of transportation, storage conditions, product safety, and environmental conditions, make it quite challenging to measure (Aramyan et al., 2007; Joshi et al., 2012). The complexity in the cold chain management often leads to nescience where the product's damage, especially products with a short shelf life (Aiello et al., 2012).

\section{Food Cold Chain Industry Expenditure Cost}

The first dimension in measuring the food cold chain's performance is costs incurred in all cold-chain operations. Managing product losses, expenditure on energy used, operating costs, maintenance of cooling systems, and expenses caused by lost time can improve the competitiveness in the supply chain (Joshi et al., 2011). Food industry waste from the loss due to microbes' decay is the most significant waste because spoilage can occur at any cold chain stage. The level of performance efficiency of the agro-food supply chain can be measured using cost indicators. Those indicators are distribution costs, transaction costs, net profit from an investment, and return on investment. The cost indicators also include company inventory costs such as products, raw materials, semifinished goods, and finished goods (Aramyan et al., 2007).

\section{Quality and Safety of Food Cold Chain Products}

Quality and safety indicators are often used to measure the food supply chain's performance. The main concerns of society are food production and consumption because they have a wide range of social, economic, and environmental consequences (Aung \& Chang, 2014b). Thus, food product problems become more customer-oriented by providing excellent and fast responses in the food industry. The increased regulations and consumer awareness regarding food safety lead researchers to research food supply chains (Kuo \& Chen, 2010). Considering the effect of low temperatures in storage along the supply chain is one of the 
Fig. 1 Food cold chain source and derivatives

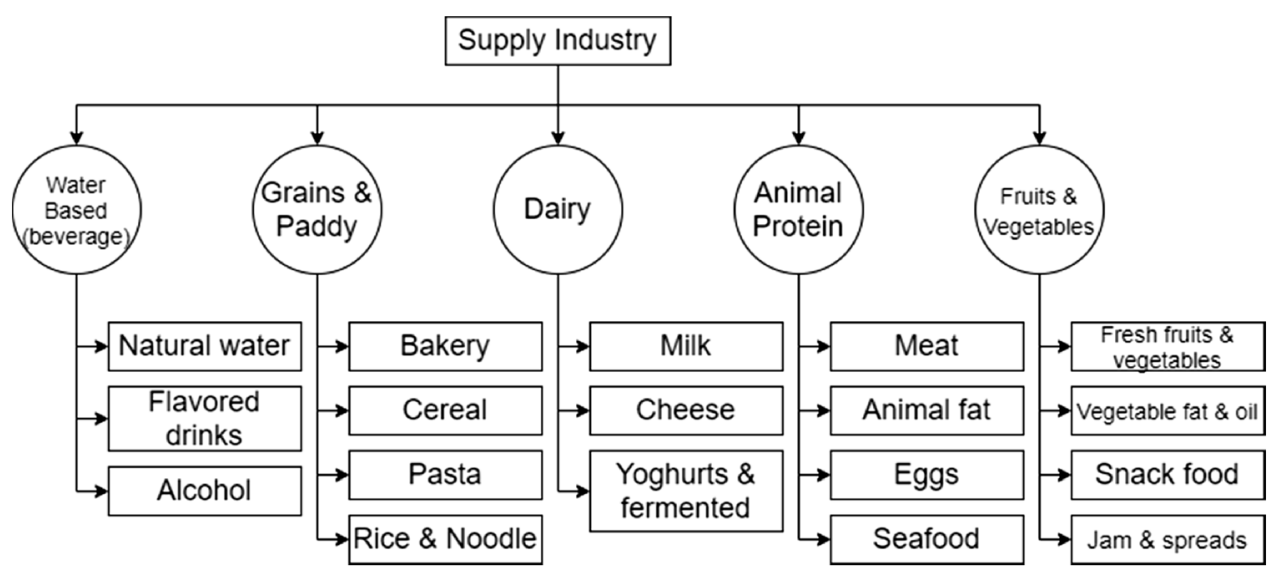

supporting aspects of improving food products' quality and safety, because that can minimize the risk of the growth of spoilage-causing microorganisms (Kuo \& Chen, 2010; Montanari, 2008; Rediers et al., 2009). Moreover, implementing worker training, recording product acceptance temperatures, setting real-time temperatures, and using an alarm system can reduce the food cold chain system's quality and safety risks (Wu \& Hsiao, 2020).

\section{Food Cold Chain Service Level}

An organization's service level provides to its customers is another dimension used as a food cold chain performance attribute. Customer satisfaction is supported by the maximum service level (Joshi et al., 2011). The cold chain uses a service level as a differentiator from other competitors. Those services include cooling systems vehicles as delivery services, flexible company operating hours, and placing a strategic company location to reach customers quickly and easily (Joshi et al., 2011). Consideration for retail companies is improving the service quality. In increasing operational efficiency and customer service, Wal-Mart implements superior supply chain management practices (Blanchard et al., 2008). These practices are maximizing sales and revenue, merging distribution centers to maintain control over shipping. Moreover, the practice also includes minimizing inventory, maximizing the use of technology to simplify the transaction process, and collaborating with suppliers to reduce product prices each year. An organization certainly could please customers by good service. Without the organization's willingness to establish an organizational culture and ensure that delivery is effective, the customer-focused services and practices cannot be developed or maintained in the long term (Bartley et al., 2007).

\section{Food Cold Chain During the Covid-19 Pandemic}

The outbreak of the Covid-19 pandemic in the world has sparked fears by the rapid virus transmission. In Indonesia, until May 2, 2021, there are 1,672,880 confirmed cases of Covid-19. Covid-19 caused by the Coronavirus 2 (SARS$\mathrm{CoV}-2$ ) by triggers acute respiratory syndrome (Wiersinga et al., 2020). The SARS-CoV-2 virus is transmitting through saliva droplets that come out of breathing during direct face-to-face contact and transmission of the virus from the surface of objects (Ganyani et al., 2020). The food supply chain's quality and safety, including the food coldchain, can be interrupted by the Covid-19 pandemic. When infected workers sneeze or cough while being in the food production supply chain, respiratory droplets could transmit Coronavirus on food products (Rizou et al., 2020). Moreover, the Covid-19 pandemic disrupts supply chain integration due to supply chain uncertainty (uncertainty of suppliers or technology) (Paul \& Chowdhury, 2020; Shukor et al., 2020). Supply and demand problems can lead to product returns, food losses, increase product prices, and trigger transportation problems for food cold chain products caused by reusable packages in product delivery; there is a risk of transmitting the virus (Masudin \& Safitri, 2020). The disruption of supply chain integration has an impact on the flexibility of the company organization. Organizational flexibility is one of the strategic dimensions for supply chain integration, and the external environment (Khoobiyan et al., 2017). Shukor et al. (2020), in their research, shows that environmental uncertainty and organizational capability are important elements that affect supply chain agility and organizational flexibility. It is more astute for companies when dealing with external uncertainties that force them to look beyond the normal limits of their business. 


\section{Traceability in the Food Cold Chain}

The possibility of Coronavirus contamination is raising more attention to the traceability of food products in the cold food chain. Applying a traceability system in food cold chains helps ensure food safety and quality to maintain consumer trust (Aung \& Chang, 2014b). When building a traceability system in a supply chain, one problem is the large scale of the food cold chain stages (production, processing, and distribution) (Bechini et al., 2008). The traceability systems allow detecting the causes of product quality problems because of the wide range from downstream of the product path along the supply chain.

According to Aiyar and Pingali (2020), it is necessary to integrate traceability technology to reduce the risk of pandemic disruption on the food system. This technology could monitor the emergence of disease in several places along the trade chain. This is very important because it can improve long-term food security by preventing the expansion of pandemics and disrupting the food system in the future. One of the food cold-chain performance matrices is the consistency in tracing product information related to origin and location (Shashi et al., 2018). There is a relationship between traceability and performance evaluation of a cold chain (Joshi et al., 2011). The track record of temperature and its origin from each stage in the cold chain may be obtained using a traceability system. Based on this description, the following hypothesis can be proposed:

H1 The traceability system (T) significantly affects the food cold chain performance (FCCP).

An effective traceability system must be flexible and responsive in identifying potential risky products and then recalling products that are declared unsafe (Mc Carthy et al., 2018). Technology needs to be supported to help trace information data along the supply chain in maximizing traceability systems in food cold chains. Advanced information technology properly adopted in a traceability system would enable strategic flexibility (Lau, 1996) when adaptable, quick, and responsive systems are highly sought to reduce environmental threats caused by the Covid-19 pandemic. During the Covid-19 pandemic, it requires minimal contacts between workers, and a flexible supply chain system needs technology that allows automation of processes on the purchasing, between suppliers, operations, and customers (Duclos et al., 2003), because flexibility considers the speed at which hardware and software architectures can change. It is necessary to allow synchronization between companies in the supply chain (Duclos et al., 2003). With a traceability system's advanced technology, the speed and accuracy of data transmission can be considered for company flexibility during pandemics.

\section{Electronic Data Interchange (EDI) Adoption}

Transmitting information from one computer to another for business transactions between organizations in the supply chain uses electronic data interchange (EDI) technology (Walton \& Marucheck, 1997). Conventional businesses such as purchase orders, material forecasting, shipping, and invoice can be replaced with EDI tools (Hart \& Saunders, 1997). EDI is important for transferring information quickly and automatically to create more effective and efficient integration or coordination (Hill \& Scudder, 2002). Maximizing EDI technology in supply chain management requires integrities between organizations (Konsynski, 1993).

Various researchers have tried the use of EDI in various industries. Ford Motor uses EDI as one of the applications to handle corporate data transfers with partners (Webster, 1995). In the retail sector, Wal-Mart uses EDI to provide real-time information with suppliers regarding order accuracy and transparency throughout its supply chain (Blanchard et al., 2008). Inventory visibility such as making invoices and payments can increase by using EDI. EDI is used to inform each department's schedule, information related to production activities, and sales activities. Companies view EDI as a tool to increase efficiency and be more accommodating to customer desires than suppliers (Hill \& Scudder, 2002). Based on this description, the following hypothesis can be proposed as follow:

$\mathrm{H} 2$ Electronic data interchange adoption (EDI) significantly affects the traceability system $(\mathrm{T})$.

\section{Radio Frequency Identification (RFID) Adoption}

Radio frequency identification (RFID) is one of the technologies often used in communication between Internet of Things (IoT) devices related to food safety (Bouzembrak et al., 2019). This technology is an identification tool that uses radio waves to detect the presence of objects through tags. RFID has many advantages: ease of use, automatic scanning, high data rates, large memory, and can scan multiple tags simultaneously (Aung \& Chang, 2014b; Musa \& Dabo, 2016; Patil \& Suresh, 2019). RFID works by transmitting radio signals through an antenna with a fixed frequency from a certain distance to form an electromagnetic field (Cao et al., 2019).

RFID use as a tracking device for items inside and outside the store in the retail industry, such as Wal-Mart (Blanchard et al., 2008). This tracking device stores goods in stores, simplifies refilling and retrieves items more 
accurately. The curbing counterfeiting and theft or increasing visibility throughout the supply chain also provide by RFID. Several researchers carried out the application of RFID technology to food cold-chain for monitoring the temperature of transport and remote storage (Abad et al., 2009; Badia-Melis et al., 2015; Jedermann et al., 2009; Ruiz-Garcia et al., 2008, 2010; Zou et al., 2014), estimating shelf life (Chen et al., 2014; Nicometo et al., 2014), monitoring of counterfeiting in food products (Rajakumar et al., 2018), and the detection of gas or volatile chemicals (Fiddes \& Yan, 2013). A similar statement was made by Óskarsdóttir and Oddsson (2019) that the most advanced technology for its integrity and traceability in the supply chain is RFID. Based on this description, the following hypothesis can be proposed:

H3 Radio frequency identification adoption (RFID) significantly affects the traceability system (T).

\section{Blockchain Adoption}

Some researchers have started to apply blockchain technology to the traceability of supply chain systems in recent years. Blockchain is a set of many blocks that contains data of all transactions within a certain period. Fingerprint scanning is used for the verification process for guaranteed validity of information and possibly connected with other blocks (Tian, 2016). The blockchain is distributed network that keeps system data open and transparent with no way to track and destroy data. Several sectors such as finance, industry, health, social, transportation, education, and agriculture have been applied blockchain technology (Cao et al., 2019).

According to Cole et al. (2019), blockchain can improve product safety and security and improve quality management. It can also reduce illegal counterfeiting, improve sustainable supply chain management, reduce the need for intermediaries, and reduce the usual supply chain transactions by implementing blockchain technology in supply chain operations and management. In the cold chain sector, to measure and monitor the entire network in a transparent and real-time manner, Kim and Shin (2019) using blockchain by considering that cold chains have a very complex structure and require different criteria for each stage and item. According to Pal and Kant (2019), the traceability of a product that all parties need in the chain uses the blockchain's information. End-users can use blockchain for obtaining product-related information that will be used to consider before buying products. Meanwhile, auditors can ensure that the processing, handling, transportation, and storage regulations have been carried out correctly. The research also includes information that blockchain can reduce the time to track information related to product contamination cases from one week to just seconds. Based on this description, the following hypothesis can be proposed:

H4 Blockchain adoption (BC) has a significant effect on the traceability system $(\mathrm{T})$.

\section{Managerial Initiatives}

In their research, Lewis and Boyle (2017) provide an overview of industry and government initiatives to improve the seafood supply chain's traceability system. The traceability system's improvement is driven by industry leaders' initiatives, pre-competitive collaboration, public-private partnerships, and government involvement with the private sector. Management initiatives in a supply chain are needed to drive the performance of a company. Some literature tries to explain the importance of an initiative in a company, such as pressure from stakeholders and retailers to affect adding value to customers and company/market performance and supply chain finance (Baert et al., 2012; Kumar et al., 2013; Martínez-Jurado \& Moyano-Fuentes, 2014; Reuter et al., 2012). Research conducted by Sousa et al. (2008) shows the Portuguese pear industry is driven by the retailer's leadership in introducing a quality assurance system and traceability along the supply chain. Masudin et al. (2018) prove that implementing green supply chain management practices (GSCM), an initiative given to the organization, has a positive and significant impact. This shows that the managerial initiative's role is critical in encouraging the sustainability of a supply chain. Moreover, the implementation of new technologies in the supply chain requires managerial attention to help increase the organizational members' willingness to learn in an uncertain field of knowledge. The managerial initiatives allow a learning process of an outward-looking and experimental without damaging ongoing efficiency-oriented activities of the organization (Khanagha et al., 2017). Based on this description, the following hypothesis can be proposed:

H5 Managerial initiatives (MIs) support traceability system (T) adoption on food cold chain performance (FCCP) improvement.

H6 Managerial initiatives (MIs) have a significant effect on the food cold chain performance (FCCP).

\section{Research Method}

This study is explanatory research with a quantitative method approach because the research variables measurement is numerical and uses statistics analysis (Nur \& Supomo, 2002). The decision of the method used is based 
on the study's objectives. The consideration for selecting the partial least square-structural equation modeling (PLSSEM) method, according to Hair et al. (2019), is when the analysis is related to testing the theoretical framework from a predictive perspective or the study conducted requires a latent variable score for follow-up analysis. This study uses the PLS-SEM method to determine whether all factors are interrelated and affect food cold chain performance. The analysis was conducted to score each latent variable and identify the construct's key driver.

This study's respondents are an expert group of consumers who have consumed food cold chain products for at least one year and retail employees who work in departments that handle food cold chain products. This study has two stages of testing: pilot and field test. There are several methods to determine a sample when the population is not known with certainty. According to Alwi (2015), a sample of 15 to 30 respondents is required for experimental and comparative research. The number of respondents used in the pilot test of this study was 30 respondents. The number of samples used for the field test was $10 \times$ the number of decided variables due to differences in sample sizes with PLS-SEM analysis (Masudin et al., 2018). So the number of field test respondents used is $10 \times 6=60$ respondents.

The results of the questionnaire were numbers from the Likert scale and analyzed using statistical methods. The use of SPSS 20.0 software helps process pilot testing data descriptively when examining the validity and reliability. Meanwhile, PLS-SEM was used to evaluating the relationship between variables using the Smart-PLS 3.2.9 software. This study measured each research variable's indicators using a questionnaire through the Google form media. The questionnaire questions are arranged based on each variable's indicators determined in the conceptual model. Measurement of the questionnaire question group uses a Likert scale with five levels; they are 5 (very important), 4 (important), 3 (neutral), 2 (less important), and 1 (not important).

\section{Conceptual Model}

The conceptual map describes the studied area and is represented by the theories compiled and describes the relationship between variables (Rowley \& Slack, 2004). The conceptual model is used to map the author's frame of mind for ease the readers to understand (as shown in Fig. 2). This model is developed based on the theory by previous researchers in the journal literature. The conceptual model describes a causal relationship and an effect between each variable. In this study, six latent variables consist of T, EDI, RFID, BC, MI, and FCCP. As for the manifest variables in this study, there were 32 attributes. The following explains the hypothesis that describes the relationship between latent variables in this study (Abad et al., 2009).

From the conceptual model above, six hypotheses were obtained, as given in Table 1.

\section{Operational Variable}

Operational variables define a concept that can be measured by determining the idea's dimensions and

Fig. 2 Conceptual model

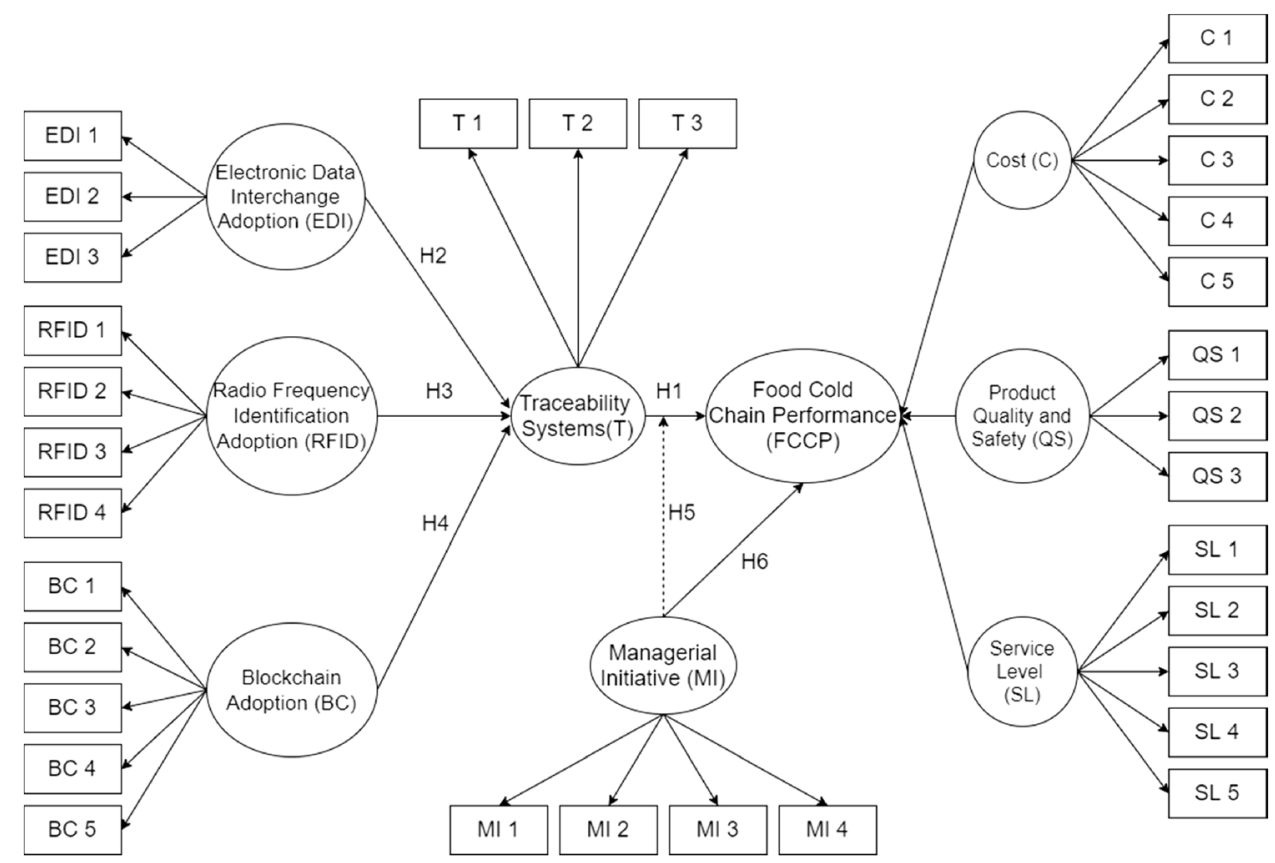


Table 1 Research hypothesis

\begin{tabular}{ll}
\hline Hypothesis & Relationship description \\
\hline H1 & T has a significant effect on FCCP \\
H2 & EDI has a significant effect on T \\
H3 & RFID has a significant effect on T \\
H4 & BC has a significant effect on T \\
H5 & MI supports FCCP to adopt T \\
H6 & MI has a significant effect on FCCP \\
\hline
\end{tabular}

characteristics (Pujihastuti, 2010). Measuring research variables can be measured by identifying operational variables by considering the variable's processes (Plumier $\&$ Maier, 2018). The author determines the operational variables by identifying them through journal literature studies. The operational variables used in this study are described in Table 2 .

\section{Results and Discussion}

\section{Pilot Test}

The questionnaire's data were obtained from 30 respondents with an age range between 18 and 49 years. The expert group consisted of 30\% women and $70 \%$ men from several western and central Indonesia areas. From the screening, it is known that $76.7 \%$ of respondents have consumed cold-chain products for more than five years and obtained products from minimarkets $(40 \%)$, supermarkets (36.7\%), and stalls/agents (23.3\%). In this test, information from retail employees is also needed due to the managerial situation comprehension in the field. Retail employees' data were obtained from 18 respondents (including 30 respondents), with $40 \%$ of respondents have only worked for less than one year. The pilot test questionnaire results were tested for validity and reliability shows in Tables 3 and 4.

Pearson correlation is used to determine the strength of research instruments in measuring precisely or determining the validity of the answers. The criterion for acceptance of validity is when the Pearson correlation value obtained is more than the $R_{\text {table }}$ value (Arikunto, 2006). The $R_{\text {table }}$ value was determined using a significance level of $5 \%$, so that the value of $R_{(n-2 ; 0.05)}=R_{(28 ; 0.05)}=0.361$. Using SPSS ver.20 software, data processing results indicate that all question items were mutually correlated between variables. Most of them had a strong correlation because those values between 0.70 and 0.89 (Schober et al., 2018). After comparing with the $\mathrm{R}_{\text {table }}$ value, it can be seen that all the questions have a Pearson correlation value that exceeds the

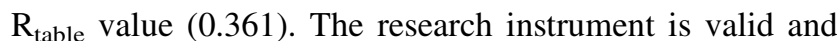
can be used for research instruments in the field test.

Research instruments need to be tested for accuracy and consistency as a means of measuring research data. This can be obtained by testing its reliability using the Cronbach's alpha test because the questionnaire has more than one correct answer (Adamson \& Prion, 2013). The acceptance criterion or a variable that can be reliable is when the Cronbach's alpha value obtained exceeds the value of 0.60 (because that is considered a strong level of relationship) (Streiner, 2003; Sugiyono, 2013). The results of data processing for reliability testing are given in Table 4. It can be concluded that all of the research variables are reliable because it has met the criteria of the rule of thumb of Cronbach's alpha. Almost all variables have a robust correlation because they value between 0.80 and 1.00 (Sugiyono, 2013). It concluded that the research instrument could be used for field tests because it has high accuracy or precision.

\section{Profile of Respondents and Descriptive Statistics of Field Test}

After ensuring the research questionnaire is valid and reliable, the field test is conducted with another data set. The field test compiles data from 220 respondents from various western, central, and eastern Indonesia regions that are given in Table 5. Most respondents have consumed cold-chain products for more than five years (72\%), so they know how the needs and urge for handling cold-chain products are supposed to do, especially during the Covid19 pandemic. Most respondents get cold food products from retailers (53\% minimarkets and 30\% supermarkets). To obtain more accurate data about the traceability system's needs and managerial conditions in the food coldchain, the authors also took samples from 93 retail employees (include in 220 respondents).

In describing the characteristics of the sample obtained, the researcher used descriptive statistics. Descriptive statistics can help researchers detect sample characteristics that can influence conclusions (Thompson, 2009). Table 6 contains descriptive statistical data in this study, which shows respondents' tendency to assess each variable indicator.

All questions (variable indicators) were answered equally by 220 responses. Most of the question indicators were responded with the highest score on the Likert scale of 5 (very important). Meanwhile, the lowest answers obtained, most of the question indicators were on Likert scale 2 (less important). For the variability of the sample data, the data have an inconsiderable range of standard deviation (between 0.662 and 0.787 ). The variation is $30 \%$, indicating that the respondent has comprehended the 
Table 2 Operational variable definition

\begin{tabular}{ll}
\hline Variable Definition & Dimension Attribute \\
\hline
\end{tabular}

EDI EDI is a tool for exchanging data between computer systems and business partners

RFID A tool to detect the presence of an object with a tag using radio frequency

$\mathrm{BC}$

Technologies with a wide range of transactions and distributed across parties from each block are continuously evolving

The traceability system detects the causes of quality and safety problems by determining their origin and characteristics from the upstream supply chain. The traceability system is for data information on food cold chains during the Covid-19 pandemic
EDI 1 EDI technology as a transaction tool in the cold chain during the Covid-19 pandemic (Foraker et al., 2020; Hart \& Saunders, 1997; Sharma \& Pai, 2015)

EDI 2 EDI is a communication system between food supply chain suppliers and consumers during the Covid-19 pandemic (Foraker et al., 2020; Hill \& Scudder, 2002)

EDI 3 EDI technology can be accessed globally on the food supply chain during the Covid-19 pandemic (Foraker et al., 2020; Hill \& Scudder, 2002; Webster, 1995)

RFID 1 Data information's suitability with actual conditions along the cold supply chain during the Covid-19 pandemic (Ho et al., 2020; Óskarsdóttir \& Oddsson, 2019)

RFID 2 The food supply chain information can be accessed quickly and easily during the Covid-19 pandemic (Aung \& Chang, 2014b; Otoom et al., 2020)

RFID 3 RFD allows tracking product temperature and humidity along the cold chain during the Covid19 pandemic (Abad et al., 2009; Garg et al., 2020)

RFID 4 There was transparency in food cold product information during the Covid-19 pandemic (Tian, 2016; Sarkis et al., 2020)

BC 1 The information system can be accessed anonymously by all parties in the food supply chain during the Covid-19 pandemic (Marbouh et al., 2020; Pal \& Kant, 2019; Tian, 2016)

BC 2 Data security on the food supply chain is guaranteed during the Covid-19 pandemic (Marbouh et al., 2020; Tian, 2016)

BC 3 The entire network's security on the food supply chain is guaranteed during the Covid-19 pandemic (Marbouh et al., 2020; Tian, 2016)

BC 4 The easy-to-access database system on the food supply chain during the Covid-19 pandemic (Marbouh et al., 2020; Tian, 2016)

BC 5 Data obtained of food cold products in real time during the Covid-19 pandemic (Kim \& Shin, 2019; Marbouh et al., 2020)

T 1 Able trace along the supply chain during the Covid-19 pandemic (Joshi et al., 2011; Onoda, 2020)

T 2 Highly detailed data tracing results (including information related to transactions, locations, product conditions, production stages, and transportation) during the Covid-19 pandemic (Sahin, Dallery, \& Gershwin, 2002; Joshi et al., 2011; Onoda, 2020) 
Table 2 continued

Variable Definition Dimension Attribute

T 3 Degree of automation in item identification and data collection along the supply chain during the Covid-19 pandemic (Joshi et al., 2011; Onoda, 2020; Sahin et al., 2002)

FCCP The food cold chain's performance during the Covid-19 Cost (C) pandemic uses a temperature control system that can inhibit microbial growth, which extends product storage life and maintains nutritional product quality
C 1 Operating costs related to service and maintenance costs in the cooling process are minimal during the Covid-19 pandemic (Joshi et al., 2011)

C 2 Food cold companies incurred minimal storage and transportation costs during the Covid-19 pandemic (Joshi et al., 2011)

C 3 Affordable refrigerated handling freight charges during the Covid-19 pandemic (Joshi et al., 2011)

C 4 Minimizing the cost of lost products expired or wasted due to mishandling during the Covid-19 pandemic (Joshi et al., 2011)

C 5 Provide training for staff who handle food cold products to improve the skills and knowledge needed during the Covid-19 pandemic (Joshi et al., 2011)

Product

QS 1 The company had quality and safety of food cold Quality and Safety (QS)

QS 2 Food cold products are continuously monitored to ensure their products' quality and safety from Coronavirus contamination (Joshi et al., 2011)

QS 3 The freshness of food cold products is maintained until the end consumer during the Covid-19 pandemic (Joshi et al., 2011)

Service

Level

SL 1 Easy-to-use transaction methods during the Covid19 pandemic (Joshi et al., 2011)

(SL)

SL 2 Comfort and convenience in reaching consumers during the Covid-19 pandemic (Joshi et al., 2011)

SL 3 Flexible operating hours during the Covid-19 pandemic (Joshi et al., 2011)

SL 4 The scope of shipping with coolers is extensive during the Covid-19 pandemic (Joshi et al., 2011)

SL 5 Complete and varied product availability during the Covid-19 pandemic (Joshi et al., 2011)

MI An action that has elements of control, theory, and purpose. It is the development of a unique terminology to distinguish different cases when the organization has the initiative (R. Cohen et al., 1998). This study analyzing managerial initiatives during the Covid-19 pandemic occurs in Indonesia driving force for other organizations to carry out
MI 1 Regulations issued by the organization as a activities in the food cold chain during the Covid-19 pandemic (Masudin et al., 2018)

MI 2 Consumption of food cold products encourages producers to trace products along the food coldchain during the Covid-19 pandemic (Masudin et al., 2018) 
Table 2 continued

\begin{tabular}{|c|c|c|c|}
\hline Variable Definition & Dimension & Attribute & \\
\hline & & MI 3 & $\begin{array}{l}\text { Food cold product supplier initiatives in } \\
\text { traceability technology can increase the food } \\
\text { cold chain effectiveness during the Covid-19 } \\
\text { pandemic (Masudin et al., 2018) }\end{array}$ \\
\hline & & MI 4 & $\begin{array}{l}\text { Several organizations in the food cold-chain } \\
\text { utilize traceability systems to maintain product } \\
\text { quality and safety during the Covid-19 } \\
\text { pandemic (Masudin et al., 2018) }\end{array}$ \\
\hline
\end{tabular}

Table 3 Validity of pilot test

\begin{tabular}{|c|c|c|c|}
\hline Variable & Indicator & Pearson correlation & Evidence \\
\hline \multirow[t]{3}{*}{ EDI } & EDI 1 & 0.886 & Valid \\
\hline & EDI 2 & 0.860 & Valid \\
\hline & EDI 3 & 0.821 & Valid \\
\hline \multirow[t]{4}{*}{ RFID } & RFID 1 & 0.736 & Valid \\
\hline & RFID 2 & 0.882 & Valid \\
\hline & RFID 3 & 0.785 & Valid \\
\hline & RFID 4 & 0.887 & Valid \\
\hline \multirow[t]{5}{*}{$\mathrm{BC}$} & BC 1 & 0.866 & Valid \\
\hline & BC 2 & 0.723 & Valid \\
\hline & BC 3 & 0.832 & Valid \\
\hline & BC 4 & 0.868 & Valid \\
\hline & BC 5 & 0.853 & Valid \\
\hline \multirow[t]{3}{*}{$\mathrm{T}$} & T 1 & 0.850 & Valid \\
\hline & Т 2 & 0.756 & Valid \\
\hline & T 3 & 0.874 & Valid \\
\hline \multirow[t]{13}{*}{ FCCP } & C 1 & 0.611 & Valid \\
\hline & C 2 & 0.584 & Valid \\
\hline & C 3 & 0.841 & Valid \\
\hline & C 4 & 0.787 & Valid \\
\hline & C 5 & 0.756 & Valid \\
\hline & QS 1 & 0.792 & Valid \\
\hline & QS 2 & 0.824 & Valid \\
\hline & QS 3 & 0.763 & Valid \\
\hline & SL 1 & 0.721 & Valid \\
\hline & SL 2 & 0.842 & Valid \\
\hline & SL 3 & 0.786 & Valid \\
\hline & SL 4 & 0.713 & Valid \\
\hline & SL 5 & 0.849 & Valid \\
\hline \multirow[t]{4}{*}{ MI } & MI 1 & 0.858 & Valid \\
\hline & MI 2 & 0.792 & Valid \\
\hline & MI 3 & 0.896 & Valid \\
\hline & MI 4 & 0.820 & Valid \\
\hline
\end{tabular}

questions comprehensively. The sample data's tendency is seen from the mean value of each indicator and variable. The QS 2 indicator (4.445) has the highest mean value, which is very important because the mean value was higher than 4.21 (Restuputri et al., 2020). This indicates that respondents consider that continuous monitoring of cold- 
Table 4 Reliability of pilot test

\begin{tabular}{lll}
\hline Variable & Cronbach's alpha & Evidence \\
\hline EDI & 0.814 & Reliable \\
RFID & 0.843 & Reliable \\
BC & 0.883 & Reliable \\
T & 0.749 & Reliable \\
FCCP & 0.930 & Reliable \\
MI & 0.860 & Reliable \\
\hline
\end{tabular}

Table 5 Respondent's profile of formal questionnaires

\begin{tabular}{lll}
\hline Profile & Frequency & Percentage $(\%)$ \\
\hline Age & & 5 \\
$<18$ & 11 & 79.5 \\
$18-25$ & 175 & 3.6 \\
$26-33$ & 8 & 2.3 \\
$34-41$ & 5 & 6.4 \\
$42-49$ & 14 & 3.2 \\
$>50$ & 7 & 46.8 \\
Gender & & 53.2 \\
Female & 103 & \\
Male & 117 & \\
Length of work & & \\
$1-5$ years & 38 & 50.9 \\
More than 5 years & 55 & \\
Education level & & 64.5 \\
High school & 142 & 6.4 \\
Diploma & 14 & 53.6 \\
Bachelor & 118 & 3.2 \\
Master & 7 & \\
\hline
\end{tabular}

chain products is critical in the traceability system. Regular monitoring is to ensure the quality and safety of its products and protected them from Coronavirus contamination.

\section{Partial Least Square-Structural Equation Modeling (PLS-SEM) Analysis}

PLS-SEM analysis is used to analyze all constructs between latent variables. This study is formed by the manifest variable (indicator) reflective model and the framework illustrated in Fig. 3. Blue circles represent latent variables connected with other latent variables, indicating the research hypothesis. Inside the blue circle, there is an R-square value of the latent variable. Meanwhile, the number contained in each research hypothesis between latent variables is the path coefficient value. The yellow box represents the manifest variable which is the measuring variable in this study. Each manifest variable's loading factor value is shown on the manifest variable arrow to the latent variable. Green circles represent moderating variables; managerial initiatives encourage traceability system variables on the food cold chain's performance.

There are two types of model fit criteria in PLS-SEM: outer and inner models. The outer model is a measurement of the relationship between variables and manifest variables in terms of validity and reliability; in other words, the outer model's suitability evaluates the measurement model, whereas the inner model is more about regression to assess the effect of one variable on other variables (construct) or it is known as the structural model evaluation (Hair et al., 2010; Tenenhaus et al., 2005). 
Table 6 Descriptive statistics of formal questionnaires

\begin{tabular}{|c|c|c|c|c|c|c|c|}
\hline Variable & Indicator & $\mathrm{N}$ & Min & Max & SD & Mean value & Mean \\
\hline \multirow[t]{3}{*}{ EDI } & EDI 1 & 220 & 2 & 5 & 0.725 & 4.232 & 4.197 \\
\hline & EDI 2 & 220 & 2 & 5 & 0.662 & 4.150 & \\
\hline & EDI 3 & 220 & 2 & 5 & 0.735 & 4.209 & \\
\hline \multirow[t]{4}{*}{ RFID } & RFID 1 & 220 & 2 & 5 & 0.754 & 4.209 & 4.177 \\
\hline & RFID 2 & 220 & 2 & 5 & 0.755 & 4.168 & \\
\hline & RFID 3 & 220 & 1 & 5 & 0.757 & 4.159 & \\
\hline & RFID 4 & 220 & 2 & 5 & 0.745 & 4.173 & \\
\hline \multirow[t]{5}{*}{$\mathrm{BC}$} & BC 1 & 220 & 2 & 5 & 0.744 & 4.186 & 4.289 \\
\hline & BC 2 & 220 & 2 & 5 & 0.715 & 4.382 & \\
\hline & BC 3 & 220 & 2 & 5 & 0.708 & 4.345 & \\
\hline & BC 4 & 220 & 1 & 5 & 0.773 & 4.264 & \\
\hline & BC 5 & 220 & 2 & 5 & 0.680 & 4.268 & \\
\hline \multirow[t]{3}{*}{$\mathrm{T}$} & Т 1 & 220 & 2 & 5 & 0.709 & 4.150 & 4.195 \\
\hline & Т 2 & 220 & 3 & 5 & 0.685 & 4.264 & \\
\hline & Т 3 & 220 & 2 & 5 & 0.707 & 4.173 & \\
\hline \multirow[t]{13}{*}{ FCCP } & C 1 & 220 & 2 & 5 & 0.761 & 4.214 & 4.324 \\
\hline & C 2 & 220 & 1 & 5 & 0.736 & 4.168 & \\
\hline & C 3 & 220 & 2 & 5 & 0.776 & 4.236 & \\
\hline & C 4 & 220 & 2 & 5 & 0.787 & 4.273 & \\
\hline & C 5 & 220 & 2 & 5 & 0.718 & 4.286 & \\
\hline & QS 1 & 220 & 2 & 5 & 0.743 & 4.400 & \\
\hline & QS 2 & 220 & 3 & 5 & 0.670 & 4.445 & \\
\hline & QS 3 & 220 & 2 & 5 & 0.700 & 4.409 & \\
\hline & SL 1 & 220 & 3 & 5 & 0.692 & 4.405 & \\
\hline & SL 2 & 220 & 2 & 5 & 0.687 & 4.414 & \\
\hline & SL 3 & 220 & 2 & 5 & 0.703 & 4.241 & \\
\hline & SL 4 & 220 & 2 & 5 & 0.705 & 4.332 & \\
\hline & SL 5 & 220 & 2 & 5 & 0.696 & 4.386 & \\
\hline \multirow[t]{4}{*}{ MI } & MI 1 & 220 & 1 & 5 & 0.747 & 4.177 & 4.224 \\
\hline & MI 2 & 220 & 2 & 5 & 0.741 & 4.164 & \\
\hline & MI 3 & 220 & 2 & 5 & 0.730 & 4.245 & \\
\hline & MI 4 & 220 & 3 & 5 & 0.712 & 4.309 & \\
\hline
\end{tabular}

\section{Evaluation of Measurement Model}

As explained in the previous section, evaluating the measurement model is conducted by assessing the latent and manifest (outer model) variables' validity and reliability. There are two types of validity in PLS-SEM, convergent validity, which refers to the correlation of indicator items with others, and discriminant validity, to determine how constructs are entirely different. The convergent validity between indicator constructs can be estimated based on the loading factor (outer loading value) and the average variant extraction (AVE) value, as shown in Table 7. Meanwhile, in term of assessing discriminant validity in general, it is done by testing the value of each cluster using the cross- loading test (Table 8) and then for a more robust assessment by comparing the square AVE value or better known as the Fornell-Larcker criterion (Table 9) (Fornell \& Larcker, 1981; Hair et al., 2011, 2016). In addition, this study also discusses the size of the model fit, as shown in Table 13. The analysis of the fit model using the PLS-SEM index in this study uses standardized root mean square residual (SRMR), normed fit index (NFI), and residual covariance matrix. . root mean square (RMS_theta) (Hair et al., 2016).

In general, reliability evaluation is defined by analyzing Cronbach's alpha value (Allen \& Yen, 2002). However, Cronbach's alpha has been criticized because its lower bound values tend to underestimate true internal 


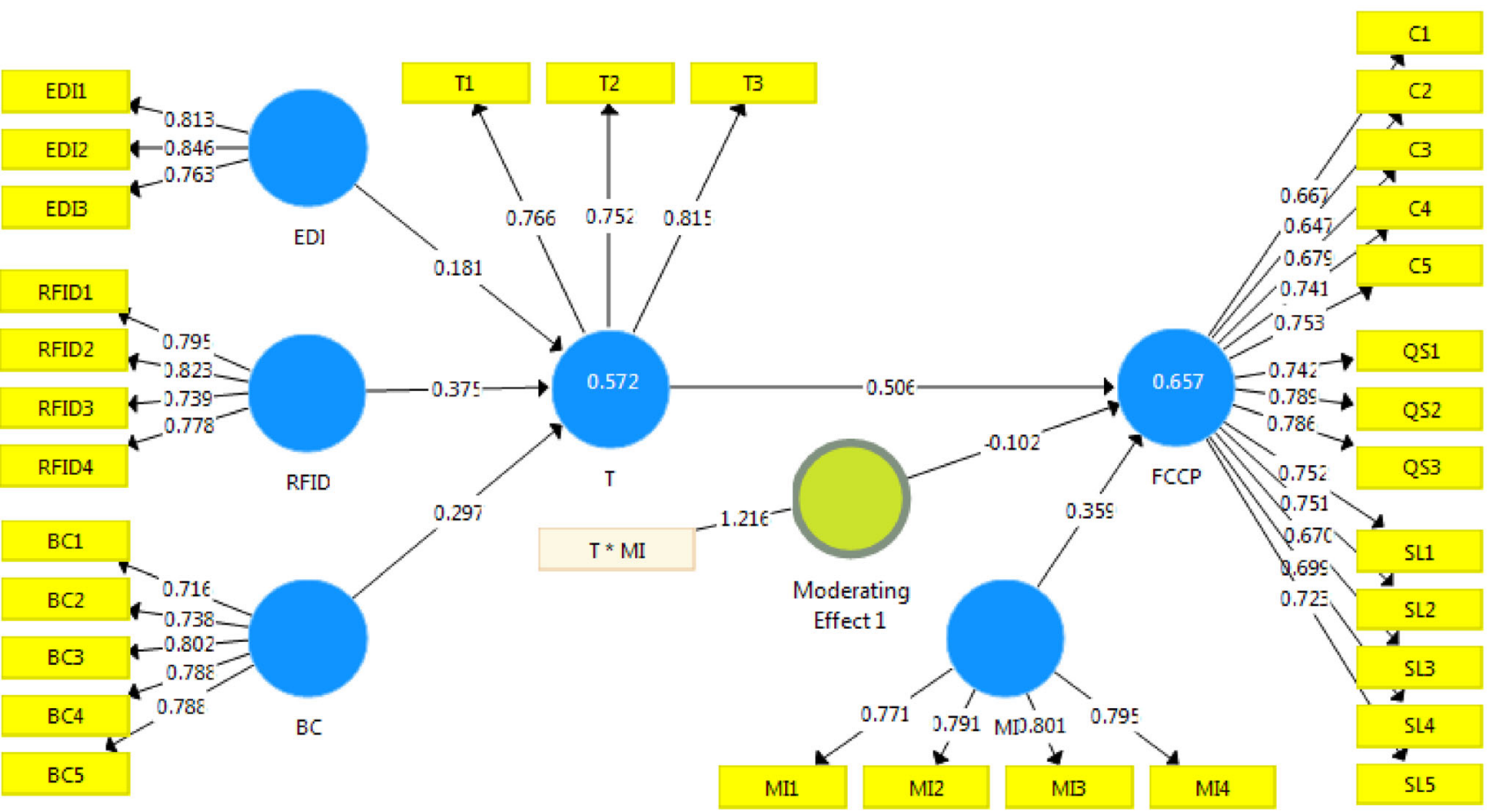

Fig. 3 Initial model

consistency reliability and are sensitive to the number of items on the scale (Nunnally, 1994; Peterson \& Kim, 2013). Composite reliability as an alternative due to the value is slightly higher than Cronbach's alpha (Peterson \& Kim, 2013). Recapitulation of the value of composite reliability is shown in Table 14.

The loading factor or outer loading value can describe each indicator item's value in measuring the variable. The outer loading rating is less than 0.4 , which is declared weak, and less than 0.7 is declared weak (Hair et al., 2011). Therefore, some researchers argue that the value of weak outer loading should be excluded from the research model. However, the deletion of these items will impact other values. Before deletion, it needs to pay more attention to the AVE value and the composite reliability value (Hair et al., 2016; Hulland, 1999). Meanwhile, according to (Ghozali, 2008), removing an indicator is when it has an outer loading value below 0.6. AVE acceptance criteria are declared valid if the value higher than 0.5 (Hair et al., 2011).

Based on the recapitulation of the outer loading and AVE values in Table 7, it can be seen that all indicator items are declared valid because the value was higher than the cutoff of the acceptance criteria for convergent validity. In addition, there were still several indicator items with weak outer loading values $(<0.7)$; there are items $\mathrm{C} 1, \mathrm{C} 2$, C 3, SL 3, and SL 4, which were FCCP variable's indicators. However, the AVE value of the FCCP variable is still acceptable. The weak indicator item is included even though it is the lowest AVE value among other variables.

The cross-loading test aims to determine the value of each cluster. The acceptance criteria is declared valid if the values between the indicators on the same variable are higher than the indicators of other variables (Hair et al., 2011, 2016). Based on this study's cross-loading test results show in Table 8, all indicator items in each variable are valid because all values in the gray box are higher than the other values in a row. This indicates that the correlation between indicator items and the variables is interrelated and valid. They are continued to the Fornell-Larcker test criteria to support discriminant validity.

In evaluating discriminant validity, the Fornell-Larcker criteria also strengthen the outer model's measurement model. The Fornell-Larcker criterion is tested to determine the correlation between variables in the research model with the rule of thumb, the value on the diagonal of the variable with the variable itself having to exceed other values in a row or a column (Fornell \& Larcker, 1981; Hair et al., 2016). Table 9 lists the Fornell-Larcker test results between variables and shows a relationship that does not meet the acceptance criteria. The correlation value for the FCCP variable is 0.724 , which is still lower than the TFCCP variable correlation value of 0.735 . This shows that the Fornell-Larcker criteria are invalid. As in research conducted by Restuputri et al. (2021), before analyzing the model's reliability, their research also ensures that Fornell- 
Table 7 Initial convergent validity recapitulation

\begin{tabular}{|c|c|c|c|c|}
\hline Variable & Indicator & Outer loading & AVE & Evidence \\
\hline \multirow[t]{3}{*}{ EDI } & EDI 1 & 0.813 & 0.653 & Valid \\
\hline & EDI 2 & 0.846 & & Valid \\
\hline & EDI 3 & 0.763 & & Valid \\
\hline \multirow[t]{4}{*}{ RFID } & RFID 1 & 0.795 & 0.615 & Valid \\
\hline & RFID 2 & 0.823 & & Valid \\
\hline & RFID 3 & 0.739 & & Valid \\
\hline & RFID 4 & 0.778 & & Valid \\
\hline \multirow[t]{5}{*}{$\mathrm{BC}$} & BC 1 & 0.716 & 0.588 & Valid \\
\hline & BC 2 & 0.738 & & Valid \\
\hline & BC 3 & 0.802 & & Valid \\
\hline & BC 4 & 0.788 & & Valid \\
\hline & BC 5 & 0.788 & & Valid \\
\hline \multirow[t]{3}{*}{$\mathrm{T}$} & $\mathrm{T} 1$ & 0.766 & 0.606 & Valid \\
\hline & Т 2 & 0.752 & & Valid \\
\hline & Т 3 & 0.825 & & Valid \\
\hline \multirow[t]{13}{*}{ FCCP } & C 1 & 0.667 & 0.525 & Valid \\
\hline & C 2 & 0.647 & & Valid \\
\hline & C 3 & 0.679 & & Valid \\
\hline & C 4 & 0.741 & & Valid \\
\hline & C 5 & 0.753 & & Valid \\
\hline & QS 1 & 0.742 & & Valid \\
\hline & QS 2 & 0.789 & & Valid \\
\hline & QS 3 & 0.786 & & Valid \\
\hline & SL 1 & 0.752 & & Valid \\
\hline & SL 2 & 0.751 & & Valid \\
\hline & SL 3 & 0.670 & & Valid \\
\hline & SL 4 & 0.699 & & Valid \\
\hline & SL 5 & 0.723 & & Valid \\
\hline \multirow[t]{4}{*}{ MI } & MI 1 & 0.771 & 0.623 & Valid \\
\hline & MI 2 & 0.791 & & Valid \\
\hline & MI 3 & 0.801 & & Valid \\
\hline & MI 4 & 0.795 & & Valid \\
\hline EDI & $\mathrm{T} * \mathrm{MI}$ & 1.216 & 1.000 & Valid \\
\hline
\end{tabular}

Larcker's recapitulation is in accordance with the criteria. This may occur because previously, we left the weak outer loading indicators affecting other tests (Hair et al., 2016; Hulland, 1999). We re-evaluated removing indicator items with weak outer loading from the research model.

The deletion of items with the outer loading $<0.7$ (C 1, C 2, C 3, SL 3, and SL 4) has impacted other loading values. This decision has also been taken before in Masudin et al., (2021a, 2021b)'s research. In their research, before continuing the measurement model evaluation, they ensured that all indicators had outer loading $>0.7$ and the AVE value $>0.5$. Based on the recapitulation in Table 10, all indicator items have exceeded the cutoff value of the outer loading and AVE criteria. Interestingly, due to the five indicator items' deletion in the FCCP variable, the AVE value of the variable was increased by 0.084 , and the lowest AVE value became the variable BC.

Re-analysis was also conducted on the cross-loading test to evaluate the discriminant validity. There are changes in some correlation values between indicator items and variables, especially in the FCCP variable's indicators. This occurs because of the effect of deleting indicator items on the same variable. However, the changes are insignificant and are still within the criteria for acceptance of crossloading so that the value test for each cluster is declared valid (Table 11). 
Table 8 Initial discriminant validity based on cross-loading

\begin{tabular}{|c|c|c|c|c|c|c|c|}
\hline & EDI & RFID & $\mathrm{BC}$ & $\mathrm{T}$ & FCCP & MI & $\mathrm{T} * \mathrm{MI}$ \\
\hline EDI 1 & 0.813 & 0.473 & 0.481 & 0.482 & 0.497 & 0.370 & -0.152 \\
\hline EDI 2 & 0.846 & 0.544 & 0.551 & 0.490 & 0.536 & 0.429 & -0.106 \\
\hline EDI 3 & 0.763 & 0.510 & 0.468 & 0.483 & 0.558 & 0.502 & -0.197 \\
\hline RFID 1 & 0.500 & 0.795 & 0.511 & 0.548 & 0.539 & 0.387 & -0.153 \\
\hline RFID 2 & 0.580 & 0.823 & 0.607 & 0.575 & 0.590 & 0.476 & -0.205 \\
\hline RFID 3 & 0.427 & 0.739 & 0.542 & 0.529 & 0.491 & 0.467 & -0.178 \\
\hline RFID 4 & 0.466 & 0.778 & 0.582 & 0.547 & 0.538 & 0.379 & -0.150 \\
\hline BC 1 & 0.486 & 0.576 & 0.716 & 0.509 & 0.489 & 0.419 & -0.152 \\
\hline BC 2 & 0.436 & 0.524 & 0.738 & 0.482 & 0.640 & 0.359 & -0.144 \\
\hline BC 3 & 0.477 & 0.597 & 0.802 & 0.523 & 0.621 & 0.418 & -0.218 \\
\hline BC 4 & 0.511 & 0.534 & 0.788 & 0.549 & 0.566 & 0.472 & -0.162 \\
\hline BC 5 & 0.462 & 0.512 & 0.788 & 0.528 & 0.561 & 0.471 & -0.174 \\
\hline T 1 & 0.479 & 0.550 & 0.536 & 0.766 & 0.521 & 0.387 & -0.029 \\
\hline T 2 & 0.430 & 0.534 & 0.502 & 0.752 & 0.609 & 0.506 & -0.190 \\
\hline T 3 & 0.494 & 0.553 & 0.542 & 0.815 & 0.583 & 0.486 & -0.086 \\
\hline C 1 & 0.467 & 0.501 & 0.573 & 0.529 & 0.667 & 0.547 & -0.152 \\
\hline C 2 & 0.460 & 0.487 & 0.479 & 0.479 & 0.647 & 0.582 & -0.211 \\
\hline C 3 & 0.481 & 0.539 & 0.539 & 0.573 & 0.679 & 0.460 & -0.108 \\
\hline C 4 & 0.543 & 0.582 & 0.630 & 0.543 & 0.741 & 0.540 & -0.201 \\
\hline C 5 & 0.516 & 0.569 & 0.540 & 0.553 & 0.753 & 0.540 & -0.215 \\
\hline QS 1 & 0.471 & 0.528 & 0.573 & 0.566 & 0.742 & 0.439 & -0.204 \\
\hline QS 2 & 0.522 & 0.566 & 0.632 & 0.575 & 0.789 & 0.441 & -0.221 \\
\hline QS 3 & 0.497 & 0.508 & 0.566 & 0.569 & 0.786 & 0.485 & -0.249 \\
\hline SL 1 & 0.412 & 0.467 & 0.529 & 0.473 & 0.752 & 0.486 & -0.224 \\
\hline SL 2 & 0.452 & 0.477 & 0.614 & 0.549 & 0.751 & 0.416 & -0.240 \\
\hline SL 3 & 0.455 & 0.448 & 0.445 & 0.495 & 0.670 & 0.513 & -0.211 \\
\hline SL 4 & 0.450 & 0.373 & 0.483 & 0.478 & 0.699 & 0.517 & -0.238 \\
\hline SL 5 & 0.435 & 0.409 & 0.429 & 0.514 & 0.723 & 0.540 & -0.289 \\
\hline MI 1 & 0.396 & 0.471 & 0.479 & 0.574 & 0.537 & 0.771 & -0.264 \\
\hline MI 2 & 0.420 & 0.432 & 0.422 & 0.444 & 0.518 & 0.791 & -0.210 \\
\hline MI 3 & 0.446 & 0.421 & 0.423 & 0.459 & 0.595 & 0.801 & -0.220 \\
\hline MI 4 & 0.431 & 0.396 & 0.444 & 0.394 & 0.535 & 0.795 & -0.212 \\
\hline $\mathrm{T} * \mathrm{MI}$ & -0.188 & -0.219 & -0.222 & -0.132 & -0.294 & -0.287 & 1.000 \\
\hline
\end{tabular}

Table 9 Initial discriminant validity based on Fornell-Larcker

\begin{tabular}{lllllll}
\hline & BC & EDI & FCCP & MI & T*MI & RFID \\
\hline BC & 0.767 & & & & & \\
EDI & 0.619 & 0.808 & & & \\
FCCP & 0.749 & 0.657 & 0.724 & & & \\
MI & 0.560 & 0.537 & 0.694 & 0.789 & & \\
T*MI & -0.222 & -0.188 & -0.294 & -0.287 & 1.000 & 0.784 \\
RFID & 0.715 & 0.630 & 0.689 & 0.545 & -0.219 & 0.701 \\
T & 0.677 & 0.601 & 0.735 & 0.592 & -0.132 & 0.778 \\
\hline
\end{tabular}


After ensuring all of the outer loading indicator items $>0.7$, it turned out to impact the Fornell-Larcker value that previously did not meet the validity acceptance. Table 12 shows the final Fornell-Larcker value on the diagonal correlation of the variable with the variable itself has higher the other values in a row or a column. The correlation value for the FCCP-FCCP variable, which was previously valued at 0.724 , increased to 0.781 , and the TFCCP correlation, which was previously valued at 0.735 , became 0.697. So it can be said that the Fornell-Larcker criteria have met the acceptance criteria, and the discriminant validity is declared valid. In addition to the model validity, we add information about the size of this study's model fit, presented in Table 13.

The SRMR describes the difference between the observed correlation and the expected correlation matrix model as an absolute measure of the fit criterion (Hair et al., 2014). If the SRMR assessment criterion is less than
0.10 or 0.08 for the more conservative version, it is considered a fit model (Hu \& Bentler, 1998). Based on the results obtained, the SRMR is $0.070<0.10$, stating the model is fit.

The NFI is an additional measure of fit, which is the value of the proposed Chi-squared model divided by the zero model's Chi-squared value (Bentler \& Bonett, 1980). The criterion for acceptance is that when the value approaches 1, the better the model is fit. The NFI value of this study is 0.912 or $91.2 \%$, and the model is fit; in other words, the model's fit is acceptable.

Only the reflective model has an RMS_theta value that explains how the outer model residuals are correlated. A good correlation is when the RMS_theta value is close to zero, which means that the outer residual correlation is minimal. In this study, the RMS_theta value was obtained at 0.103 , indicating that the model is fit because it is less than 0.12 (Hair et al., 2014). Based on the three parameters

Table 10 Final convergent validity recapitulation

\begin{tabular}{|c|c|c|c|c|}
\hline Variable & Indicator & Outer loading & AVE & Evidence \\
\hline \multirow[t]{3}{*}{ EDI } & EDI 1 & 0.813 & \multirow[t]{3}{*}{0.653} & Valid \\
\hline & EDI 2 & 0.846 & & Valid \\
\hline & EDI 3 & 0.763 & & Valid \\
\hline \multirow[t]{4}{*}{ RFID } & RFID 1 & 0.795 & \multirow[t]{4}{*}{0.615} & Valid \\
\hline & RFID 2 & 0.823 & & Valid \\
\hline & RFID 3 & 0.739 & & Valid \\
\hline & RFID 4 & 0.778 & & Valid \\
\hline \multirow[t]{5}{*}{$\mathrm{BC}$} & BC 1 & 0.716 & \multirow[t]{5}{*}{0.588} & Valid \\
\hline & BC 2 & 0.738 & & Valid \\
\hline & BC 3 & 0.802 & & Valid \\
\hline & BC 4 & 0.788 & & Valid \\
\hline & BC 5 & 0.788 & & Valid \\
\hline \multirow[t]{3}{*}{$\mathrm{T}$} & $\mathrm{T} 1$ & 0.766 & \multirow[t]{3}{*}{0.606} & Valid \\
\hline & Т 2 & 0.754 & & Valid \\
\hline & Т 3 & 0.813 & & Valid \\
\hline \multirow[t]{8}{*}{ FCCP } & $\mathrm{C} 4$ & 0.747 & \multirow[t]{8}{*}{0.609} & Valid \\
\hline & C 5 & 0.770 & & Valid \\
\hline & QS 1 & 0.793 & & Valid \\
\hline & QS 2 & 0.826 & & Valid \\
\hline & QS 3 & 0.826 & & Valid \\
\hline & SL 1 & 0.767 & & Valid \\
\hline & SL 2 & 0.782 & & Valid \\
\hline & SL 5 & 0.727 & & Valid \\
\hline \multirow[t]{4}{*}{ MI } & MI 1 & 0.777 & \multirow[t]{4}{*}{0.622} & Valid \\
\hline & MI 2 & 0.783 & & Valid \\
\hline & MI 3 & 0.803 & & Valid \\
\hline & MI 4 & 0.793 & & Valid \\
\hline Moderating effect (MI supports FCCP to adopt T) & $\mathrm{T}^{*} \mathrm{MI}$ & 1.217 & 1.000 & Valid \\
\hline
\end{tabular}


Table 11 Final discriminant validity based on cross-loading

\begin{tabular}{|c|c|c|c|c|c|c|c|}
\hline & EDI & RFID & $\mathrm{BC}$ & $\mathrm{T}$ & FCCP & MI & $\mathrm{T} * \mathrm{MI}$ \\
\hline EDI 1 & 0.813 & 0.473 & 0.481 & 0.482 & 0.457 & 0.37 & -0.152 \\
\hline EDI 2 & 0.846 & 0.544 & 0.551 & 0.49 & 0.511 & 0.429 & -0.107 \\
\hline EDI 3 & 0.763 & 0.51 & 0.468 & 0.483 & 0.53 & 0.501 & -0.198 \\
\hline RFID 1 & 0.500 & 0.795 & 0.511 & 0.548 & 0.522 & 0.386 & -0.154 \\
\hline RFID 2 & 0.580 & 0.823 & 0.607 & 0.575 & 0.560 & 0.476 & -0.205 \\
\hline RFID 3 & 0.427 & 0.739 & 0.542 & 0.530 & 0.459 & 0.468 & -0.180 \\
\hline RFID 4 & 0.466 & 0.778 & 0.582 & 0.547 & 0.526 & 0.381 & -0.152 \\
\hline BC 1 & 0.486 & 0.576 & 0.716 & 0.509 & 0.448 & 0.419 & -0.155 \\
\hline BC 2 & 0.436 & 0.524 & 0.738 & 0.482 & 0.63 & 0.36 & -0.144 \\
\hline BC 3 & 0.477 & 0.597 & 0.802 & 0.523 & 0.626 & 0.418 & -0.219 \\
\hline BC 4 & 0.511 & 0.534 & 0.788 & 0.55 & 0.533 & 0.473 & -0.164 \\
\hline BC 5 & 0.462 & 0.512 & 0.788 & 0.528 & 0.542 & 0.472 & -0.176 \\
\hline T 1 & 0.479 & 0.550 & 0.536 & 0.766 & 0.494 & 0.389 & -0.029 \\
\hline Т 2 & 0.430 & 0.534 & 0.502 & 0.754 & 0.590 & 0.507 & -0.192 \\
\hline Т 3 & 0.494 & 0.553 & 0.542 & 0.813 & 0.541 & 0.488 & -0.086 \\
\hline C 4 & 0.543 & 0.582 & 0.630 & 0.543 & 0.747 & 0.541 & -0.202 \\
\hline C 5 & 0.516 & 0.569 & 0.540 & 0.554 & 0.770 & 0.540 & -0.216 \\
\hline QS 1 & 0471 & 0.528 & 0.573 & 0.566 & 0.793 & 0.442 & -0.205 \\
\hline QS 2 & 0.522 & 0.566 & 0.632 & 0.575 & 0.826 & 0.442 & -0.221 \\
\hline QS 3 & 0.497 & 0.508 & 0.566 & 0.570 & 0.826 & 0.487 & -0.250 \\
\hline SL 1 & 0.412 & 0.467 & 0.529 & 0.473 & 0.767 & 0.486 & -0.226 \\
\hline SL 2 & 0.452 & 0.477 & 0.614 & 0.549 & 0.782 & 0.419 & -0.242 \\
\hline SL 5 & 0.435 & 0.409 & 0.429 & 0.514 & 0,727 & 0.539 & -0.290 \\
\hline MI 1 & 0.396 & 0.471 & 0.479 & 0.574 & 0.503 & 0.777 & -0.265 \\
\hline MI 2 & 0.420 & 0.432 & 0.422 & 0.444 & 0.441 & 0.783 & -0.210 \\
\hline MI 3 & 0.446 & 0.421 & 0.423 & 0.459 & 0.546 & 0.803 & -0.221 \\
\hline MI 4 & 0.431 & 0.396 & 0.444 & 0.393 & 0.474 & 0.793 & -0.211 \\
\hline $\mathrm{T} * \mathrm{MI}$ & -0.188 & -0.221 & -0.224 & -0.133 & -0.297 & -0.288 & 1.000 \\
\hline
\end{tabular}

Table 12 Final discriminant validity based on Fornell-Larcker

\begin{tabular}{lllllll}
\hline & BC & EDI & FCCP & MI & T*MI & RFID \\
\hline BC & 0.767 & & & & \\
EDI & 0.619 & 0.808 & & & \\
FCCP & 0.723 & 0.619 & 0.781 & & \\
MI & 0.560 & 0.537 & 0.626 & 0.789 & & \\
T*MI & -0.224 & -0.188 & -0.297 & -0.288 & 1.000 & 0.784 \\
RFID & 0.715 & 0.630 & 0.660 & 0.545 & -0.221 & 0.701 \\
T & 0.677 & 0.601 & 0.697 & 0.595 & -0.133 & 0.778 \\
\hline
\end{tabular}

of the fit model analyzed, it can be concluded that the model has shown a good fit. Similar findings with Masudin et al., (2021a, 2021b) research examined the effect of traceability on humanitarian logistics performance. The research obtained an SRMS value of 0.081 , NFI of $92.3 \%$, and RMS_theta of 0.099 , which indicates the right model.
The reliability test's composite reliability parameters aim to know the relationship of the load outside the construct, which is insufficient if using Cronbach's alpha parameters (Fornell \& Larcker, 1981; Hair et al., 2016). The composite reliability parameter's acceptance criteria are when the value is between 0.6 and 0.7 , including 
Table 13 Recapitulation of model fit

\begin{tabular}{lr}
\hline PLS-SEM index & Estimated model \\
\hline SRMR & 0.070 \\
NFI & 0.912 \\
RMS_theta & 0.103 \\
\hline
\end{tabular}

having moderate and acceptable reliability. In contrast, if the value of composite reliability reaches 0.7 to 0.9 , it is declared strong. In Table 14, a recapitulation of this study's composite reliability value is listed. The lowest value of 0.822 belongs to the traceability system $(\mathrm{T})$ and the highest of 1.000 for the moderating effect between the traceability system and managerial initiatives ( $\mathrm{T} * \mathrm{MI})$. Based on the composite reliability parameter's acceptance criteria, all variables are declared reliable with a strong level of reliability and show the magnitude of the phenomenon for all the identical indicator items in the same construct.

\section{Evaluation of Structural Model}

Structural model evaluation was conducted to evaluate the inner relationships of this research model. Figure 4 shows a valid and reliable research model. Furthermore, the model has analyzed the coefficient of determination and path coefficient.

The coefficient of determination or R-square describes the latent variable's variance explained by other latent variables (Hair et al., 2011, 2016). In Fig. 4, the R-square value is shown on the endogenous variable icon; the traceability system variable is 0.572 , and the food cold chain performance variable is 0.575 . The $\mathrm{R}$-square value of the two endogenous variables was included in the prediction accuracy moderate because the values ranged from 0.33 to 0.67 (Ghozali, 2008). This shows that the traceability system variable can be defined by $57.2 \%$ and the remaining $42.8 \%$ contribution of other variables that are not discussed in this study. The food cold chain performance variable can be defined by $57.5 \%$, and the remaining $42.5 \%$ are not discussed in this study. Those values defined more than half of the total explanation required. Masudin and et al., (2021a, 2021b), in their research on the humanitarian logistics performance variable, obtained an R-square value of $57.3 \%$, which also only defined half of the overall explanation for the variable.

Path coefficient analysis explains latent variables' relationship to other latent variables by knowing the direction of these variables (positive or negative) (Hair et al., 2016). Table 15 summarizes the path coefficient values obtained using a bootstrapping technique. The path coefficient criteria are less than 0.15 , which is considered weak, the values of $0.15-0.45$ are stated to be moderate, and if the value is more than 0.45, it is declared strong (Cohen, 1992). As many as five variables in the research model show a moderate to a strong positive relationship, only the moderating effect variable negatively correlates with the food cold chain performance variable.

\section{Hypothesis Testing}

Hypothesis testing aims to determine the influence of exogenous, endogenous, and moderating variables. The test acceptance criteria if the T-statistical value $\geq \mathrm{T}$-table or P-value $\leq$ level of significance $(\alpha)$ (Hair et al., 2016). This study uses a significant level of $5 \%$ with a two-tailed test, so the T-table value used is 1.96 . The following are the results of hypothesis testing using bootstrapping techniques.

Table 14 Reliability of formal questioners

\begin{tabular}{llr}
\hline Variable & Composite reliability & Evidence \\
\hline EDI & 0.849 & Reliable \\
RFID & 0.865 & Reliable \\
BC & 0.877 & Reliable \\
T & 0.822 & Reliable \\
FCCP & 0.926 & Reliable \\
MI & 0.868 & Reliable \\
Moderating effect (MI supports FCCP to adopt T) $\left(\mathrm{T}^{*} \mathrm{MI}\right)$ & 1.000 & Reliable \\
\hline
\end{tabular}




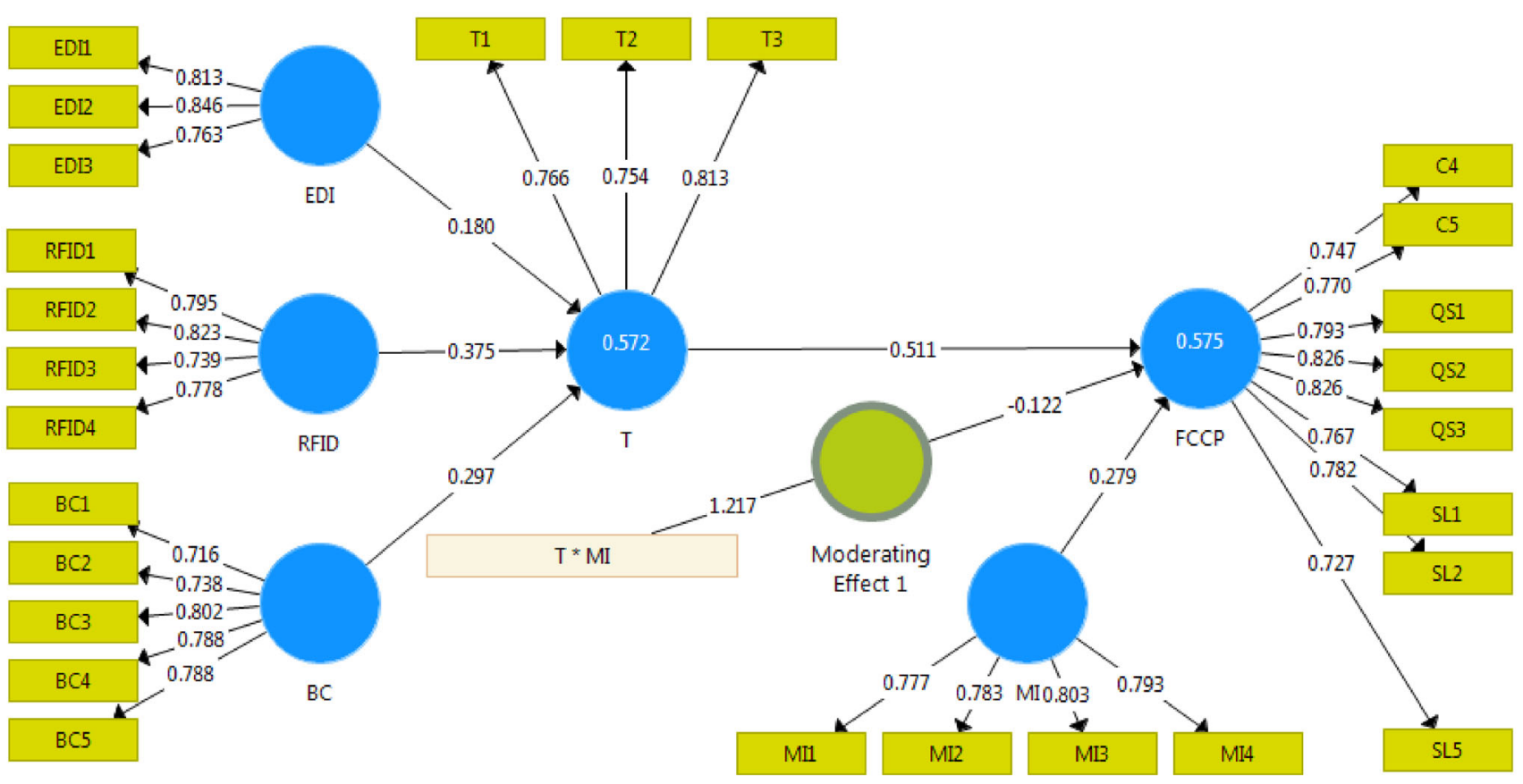

Fig. 4 Final model

Table 15 Path coefficient recapitulation

\begin{tabular}{lll}
\hline Variable & T & FCCP \\
\hline EDI & 0.180 \\
RFID & 0.375 \\
BC & 0.297 \\
T & & 0.511 \\
MI & & 0.279 \\
Moderating effect (MI will support FCCP to adopt T) & & -0.122 \\
\hline
\end{tabular}

The evaluation using bootstrapping techniques affects the acceptance of this research hypothesis. The following is a further explanation of the findings in Table 16.

\section{H1 T has a significant effect on FCCP.}

The statistical value calculation for the relationship between $\mathrm{T}$ and FCCP variables obtained a t-statistic value of 9.656 and a p-value of 0.000 . These results are met with the acceptance criteria of the hypothesis test. Therefore, it can be concluded that the traceability system has a positive and significant effect on the performance of the food coldchain. Furthermore, this hypothesis has the highest t-statistic value among other variables, which shows that the traceability system's impact in obtaining information data along the cold-chain chain helps improve industrial performance during the Covid-19 pandemic. These results are relevant to previous studies.
The ongoing Covid-19 pandemic has triggered social restriction policies that disrupt activities along the food cold-chain. The possibility of virus contamination in food cold chain products requires a health protocol during the product handling process. This caused increased processing time and reduced worker movement. The characteristics of most food cold chain products are easily damaged and have a relatively short product life, so it needs to be handled quickly and swiftly in order to keep a good product quality (Bogataj et al., 2005; Shabani et al., 2015; Shashi et al., 2018). Slow and uncontrolled handling can cause food losses triggered by food damage before it reaches the end consumer. This phenomenon creates an unusual routine for workers. One of the managerial tasks, in this case, involves the creation or promotion of dynamic capabilities. Dynamic capabilities spur managerial initiatives to modify the company's resource base or regular routines and will increase management control capabilities in general 
Table 16 Bootstrapping recapitulation

\begin{tabular}{lllll}
\hline Hypothesis & Relationship description & T-statistic & P-value & Evidence \\
\hline H1 & T has a significant effect on FCCP & 9.656 & 0.000 & Significant \\
H2 & EDI has a significant effect on T & 2.486 & 0.013 & Significant \\
H3 & RFID has a significant effect on T & 5.018 & 0.000 & Significant \\
H4 & BC has a significant effect on T & 3.884 & 0.000 & Significant \\
H5 & MI supports FCCP to adopt T & 3.428 & 0.001 & Significant \\
H6 & MI has a significant effect on FCCP & 4.667 & 0.000 & Significant \\
\hline
\end{tabular}

(Huber, 2011; Volberda, 2003; Winter, 2003). Managerial initiatives also need operational flexibility to respond to expected changes rapidly and aim to maximize efficiency and minimize risk in volatile markets (van der Weerdt et al., 2012; Volberda, 1996; Zollo \& Winter, 2002).

The traceability system can ensure the product's condition while monitoring the product storage temperature (Joshi et al., 2011). Proper temperature control along the food cold-chain is needed to reduce microbial growth to prevent micronutrients in food products (Joshi et al., 2011; Liao et al., 2011; Shashi et al., 2018). Moreover, suppose a case of Covid-19 contamination is found in the food coldchain. In that case, the traceability system can help trace the origin of the product and facilitate handling other Covid-19 cases. Extra services with a traceability system can increase customer satisfaction and trust in food cold products' quality and safety (Joshi et al., 2011). Thus, a good and effective traceability system helps improve the food cold chain's performance during the Covid-19 pandemic.

\section{H2 EDI significantly affects $\mathrm{T}$.}

The calculation of the EDI variable's statistical value with the $\mathrm{T}$ variable obtained a T-statistical value of 2.486 and a p-value of 0.013 . These results have met the criteria for acceptance of the hypothesis test. Therefore, it is concluded that the variable adoption of electronic data interchange has a positive and significant effect on the traceability system variable. However, it should also be noted that the EDI variable has the lowest considerable value compared to other technology adoption variables (RFID and blockchain). This shows that electronic data interchange adoption has a low effect on the traceability system of food cold-chain product data information during the Covid-19 pandemic.

In addition to the advantages offered, EDI technology also has several disadvantages such as complicated use and sizeable initial capital costs, and does not even have the security required by some companies (Scala \& McGrath, 1993). Increasing the ability to track product units along the supply chain will be more effective and efficient if it relies on EDI technology in its internal management system (Hu et al., 2013). EDI allows fast and accurate data transmission and a minimum of recurring errors (Scala \& McGrath, 1993). This can improve the relationship between customers and suppliers, which helps flexibility in responding to changes in demand and unexpected supply disruptions during the Covid-19 pandemic (Hobbs, 2020; Scala \& McGrath, 1993).

\section{H3 RFID has a Significant Effect on T.}

Based on statistical calculations, the t-statistic value for the T variable's RFID variable is 5.018, and the p-value is 0.000 . Thus, both values have met the acceptance criteria of the t-statistic and p-value parameters. Thus, it can be concluded that the variable radio frequency identification adoption has a positive and significant effect on the traceability system variable. Interestingly, the RFID variable is the technology adoption variable that has the most significant value. This shows that RFID technology is influential and effective in helping traceability systems collect better information on the food cold-chain during the Covid-19 pandemic. These results are also relevant to previous studies.

RFID technology's potential in wholesale supply chain traceability systems is proved to provide operational efficiency and increase product stocks' transparency with a short shelf life (Kärkkäinen, 2003). This may happen because RFID has a tag that makes it easy-to-access information on the product's date of use (Nicola et al., 2020). In addition, RFID technology is also applied to food cold chains to monitor product temperature along the chain (Abad et al., 2009; Badia-Melis et al., 2015; Jedermann et al., 2009; Ruiz-Garcia et al., 2010; Zou et al., 2014). Temperature control errors are among the top five food quality and safety risks in the food cold-chain $(\mathrm{Wu} \&$ Hsiao, 2020). The possibility of food losses due to decreased product quality and safety occurred during the Covid-19 pandemic and impacted the food cold-chain (Masudin \& Safitri, 2020). In addition, it currently requires a monitoring system along the food cold-chain to anticipate Coronavirus transmission in food colds (Han et al., 2021). 


\section{H4 BC has a Significant Effect on T.}

Based on Table 16, the relationship between the variable $\mathrm{BC}$ and the variable $\mathrm{T}$ obtained a t-statistic value of 3.884 and a p-value of 0.000 . These results also meet the acceptance criteria of the hypothesis. So, it can be concluded that the blockchain adoption variable has a positive and significant relationship to the traceability system. Blockchain technology was able to help the food coldchain traceability system during the Covid-19 pandemic. These results are relevant to previous studies on a similar topic.

Food safety and consumer confidence in the food industry can be significantly improved by utilizing blockchain technology (Tian, 2016). Blockchain technology can provide real-time information to all entities in the supply chain. In addition, blockchain can also reduce the risk of centralized information systems, more secure, distributed, transparent, and collaborative. This capability certainly makes it easier to monitor food quality and safety tracing. As previously explained, there are case findings that the Coronavirus can survive and be stable for 14-21 days in cold and freezing conditions. With comprehensive and real-time monitoring, blockchain can assist the safety and quality of products in the food cold-chain during the Covid-19 pandemic (Han et al., 2021). Blockchain technology in helping the traceability system is quite important given the many advantages it has.

\section{H5 MI supports T adoption on FCCP improvement.}

Based on the hypothesis test in Table 16, it is found that the t-statistical value of the MI variable in supporting the adoption of the $\mathrm{T}$ variable in the FCCP variable is 3,428 , and the p-value is 0.001 . These results have met the acceptance criteria of the hypothesis. However, based on the bootstrapping results in Table 14, the managerial initiative variable shows a negative relationship with the food cold chain performance variables. Therefore, it can be concluded that managerial initiatives negatively support traceability system adoption on food cold chain performance improvement.

This finding is different from the previous research conducted by Lewis and Boyle (2017). His study shows the positive influence of industry-leading initiatives, pre-competitive collaboration, partnerships, and government involvement in improving the traceability system. This difference may occur because sometimes, the participation of certain parties can cause a negative influence. Collier et al. (2004) explained that cultural inertia, increased politics, and more constrained strategy could negatively affect the quality of strategic decisions and implementation efficiency. Over-initiative tends to lead to unnecessary interference and may result in an ineffective strategy. When power and politics are very dominant, it can distort information and reduce strategic decisions' quality. The urgency of fulfilling needs during the Covid-19 pandemic has triggered many parties to abuse their policies to gain personal benefits. Therefore, implementing a traceability system to improve food cold chains' performance requires the involvement of managerial initiatives that are more structured and strategic.

\section{H6 MI significantly affects FCCP.}

The hypothesis testing results indicate that managerial initiatives positively and significantly affect the food cold chain's performance. This conclusion is based on the t-statistic of the management initiative variable on the FCCP variable. It shows that t-statistics is $4.667>\mathrm{t}_{\text {table }}$ (1.96) and the p-value of $0.000<\operatorname{sig}(0.05)$. This is in accordance with several previous studies which state that added value for customers and company/supply chain performance can be improved thanks to initiatives such as pressure from stakeholders (Baert et al., 2012; Kumar et al., 2013; Martínez-Jurado \& Moyano-Fuentes, 2014; Reuter et al., 2012). For example, food safety status can be increased by creating a food policy or initiative taken by risk managers in the food industry (Baert et al., 2012). This allows for an increase in the food cold chain's performance due to stakeholder involvement in decision-making or strategy. During the Covid-19 pandemic, an effective and efficient policy was needed because, as previously discussed, the food cold chain means dealing with easily damaged products. The quality of food cold products will gradually decline if it is not handled properly (such as temperature monitoring or human handling). There needs to be concern and participation from all parties to realize good quality and safety in the food cold-chain during the pandemic because it is prone to Coronavirus transmission. So, the most important thing from the harmful effect of decreasing product quality and safety is the possibility of reduced food losses.

\section{Managerial Implications}

This section is expected to provide theoretical contributions to improve the food cold chain's performance. The compilation of managerial implications is based on the indicators with the highest factor loading values on exogenous and moderating variables. Researchers gave the following suggestions to parties in the food cold-chain during the Covid-19 pandemic:

1. Adopting electronic data interchange technology as a communication system between food supply chain suppliers and consumers during the Covid-19 
pandemic is beneficial. One of EDI technology's advantages is that it allows for the fast distribution of information and the minimum number of errors (Scala \& McGrath, 1993). In other words, this technology has a high level of information accuracy. However, in reality, companies view EDI as a tool to increase efficiency and accommodate customer needs rather than suppliers (Hill \& Scudder, 2002). Therefore, more attention is needed because EDI between suppliers and consumers (such as retail) can provide ordering accuracy and transparency in the food cold-chain during the Covid-19 pandemic.

2. The food supply chain information can be accessed quickly and easily during the Covid-19 pandemic. As explained in the previous section, fast and easily accessible information is very important because coldchain products tend to be short-lived. Radio frequency identification technology can help provide information more effectively and efficiently because it uses large memory and automatic scanning simultaneously (Aung \& Chang, 2014b). The advantages of RFID make it possible to help the availability of information systems easily accessible during the Covid-19 pandemic.

3. The security of the entire network on the food supply chain is guaranteed during the Covid-19 pandemic. The blockchain database system integrates all data blocks and creates a distributed network (Tian, 2016). The blockchain's massive database system concerns some parties regarding the data's security being stored. Moreover, all information on the blockchain is transparent, open, neutral, and reliable (Tian, 2016). Therefore, the security of the blockchain system needs to be considered so that data are not easily damaged.

4. Food cold product supplier initiatives in traceability technology can increase the food cold chain's effectiveness during the Covid-19 pandemic. The traceability system has proved to improve the performance of food cold-chain during the Covid-19 pandemic. However, the implementation of a good traceability system, of course, depends on the user whether it has been implemented optimally or not. Therefore, suppliers of the last goods (before retail) play a significant role in product availability. Therefore, an industry can be encouraged with good leadership to generate a strategy for quality assurance and traceability along the supply chain.

\section{Conclusion and Limitations}

\section{Conclusion}

This study discusses how food cold-chain performance can be improved during the current Covid-19 pandemic worldwide. Adopting an information system can help trace product data information on the possibility of Coronavirus transmission. The researcher added that managerial initiatives were the driving factor for the adoption of the traceability system. Six research hypotheses were formulated based on previous research literature studies with a similar topic. A total of 250 respondents from various Indonesian regions participated in this study to answer the 32 questions given in a questionnaire. Finally, the data were collected and analyzed further in Sect. 5, along with a detailed discussion.

Many previous studies have presented descriptions of what impacts the Covid-19 pandemic has had on the food industry. Starting from food safety issues, product availability, and food losses caused by deteriorating food quality. This study shows that traceability system technologies such as EDI, RFID, and blockchain are beneficial for food cold-chain during the Covid-19 pandemic. By equipped with various advantages, these technologies can facilitate easy-to-access information and monitor food cold-chain. However, it should be noted that excessive involvement in managerial initiatives can make things worse. The excessive interference from the dominant party in their power can disrupt adopting the traceability system.

\section{Limitations}

This research has limitations which are the scope of the study. This research only refers to the needs of users and retail employees who have consumed and or handled coldchain products. In addition, responses were collected based on the perspective of the Covid-19 pandemic in Indonesia. It is expected that the proposed application of a traceability system with managerial initiatives can help improve the performance of food cold chains in Indonesia, as summarized in the managerial implication. Future studies can use different respondents and circumstances/perspectives or use different variables in adopting a traceability system to improve the performance of food cold chains. Different methods for selecting traceability system requirements are also possible, such as clustering indicators by calculating their weights.

Acknowledgements We would like to thank the reviewers for their appreciated and exceptional contribution by providing critical feedback and comments to improve the manuscript. We would like to thank the editors and editor-in-chief for their encouragement and 
background in keeping the paper at this level of quality. We would like to thank the Engineering Faculty of the University of Muhammadiyah Malang for full supports to complete the research.

Funding No funding was received to assist with the preparation of this manuscript.

\section{Declarations}

Conflict of interest The authors hereby declare that there are no potential conflicts of interest in terms of authorship, research, and/or publication of this article.

Informed Consent There are no human subjects in this article, and informed consent is not applicable.

\section{References}

Abad, E., Palacio, F., Nuin, M., De Zarate, A. G., Juarros, A., Gómez, J. M., \& Marco, S. (2009). RFID smart tag for traceability and cold chain monitoring of foods: Demonstration in an intercontinental fresh fish logistic chain. Journal of Food Engineering, 93(4), 394-399.

Adamson, K. A., \& Prion, S. (2013). Reliability: Measuring internal consistency using Cronbach's $\alpha$. Clinical Simulation in Nursing, 9(5), e179-e180.

Aiello, G., La Scalia, G., \& Micale, R. (2012). Simulation analysis of cold chain performance based on time-temperature data. Production Planning \& Control, 23(6), 468-476.

Aiyar, A., \& Pingali, P. (2020). Pandemics and food systems-towards a proactive food safety approach to disease prevention \& management. Food Security, 12(4), 749-756.

Allen, M., \& Yen, W. (2002). Introduction to measurement theory. 4 (printing). Waveland Press Inc.

Alwi, I. (2015). Kriteria empirik dalam menentukan ukuran sampel pada pengujian hipotesis statistika dan analisis butir. Formatif: Jurnal Ilmiah Pendidikan MIPA, 2(2), 140-148.

Aramyan, L. H., Lansink, A. G. O., Van Der Vorst, J. G., \& Van Kooten, O. (2007). Performance measurement in agri-food supply chains: A case study. Supply Chain Management: An International Journal, 12(4), 304-315.

Arikunto, S. (2006). Metodelogi penelitian. Yogyakarta: Bina Aksara.

Aung, M. M., \& Chang, Y. S. (2014a). Temperature management for the quality assurance of a perishable food supply chain. Food Control, 40, 198-207.

Aung, M. M., \& Chang, Y. S. (2014b). Traceability in a food supply chain: Safety and quality perspectives. Food Control, 39, 172-184.

Badia-Melis, R., Ruiz-Garcia, L., Garcia-Hierro, J., \& Villalba, J. I. R. (2015). Refrigerated fruit storage monitoring combining two different wireless sensing technologies: RFID and WSN. Sensors, 15(3), 4781-4795.

Baert, K., Van Huffel, X., Jacxsens, L., Berkvens, D., Diricks, H., Huyghebaert, A., \& Uyttendaele, M. (2012). Measuring the perceived pressure and stakeholders' response that may impact the status of the safety of the food chain in Belgium. Food Research International, 48(1), 257-264.

Bartley, B., Gomibuchi, S., \& Mann, R. (2007). Best practices in achieving a customer-focused culture. Benchmarking: An International Journal, 14(4), 482-496.

Bechini, A., Cimino, M. G., Lazzerini, B., Marcelloni, F., \& Tomasi, A. (2005). A general framework for food traceability. Paper presented at the 2005 Symposium on Applications and the Internet Workshops (SAINT 2005 Workshops).
Bechini, A., Cimino, M. G., Marcelloni, F., \& Tomasi, A. (2008). Patterns and technologies for enabling supply chain traceability through collaborative e-business. Information and Software Technology, 50(4), 342-359.

Bentler, P. M., \& Bonett, D. G. (1980). Significance tests and goodness of fit in the analysis of covariance structures. Psychological Bulletin, 88(3), 588.

Blanchard, C., Comm, C. L., \& Mathaisel, D. F. (2008). Adding value to service providers: Benchmarking Wal-Mart. Benchmarking: An International Journal, 15(2), 166-177.

Bogataj, M., Bogataj, L., \& Vodopivec, R. (2005). Stability of perishable goods in cold logistic chains. International Journal of Production Economics, 93, 345-356.

Bouzembrak, Y., Klüche, M., Gavai, A., \& Marvin, H. J. (2019). Internet of Things in food safety: Literature review and a bibliometric analysis. Trends in Food Science \& Technology, 94, 54-64.

BPS. (2019). Badan Pusat Statistik. from http://www.bps.go.id/

Cao, Y., Jia, F., \& Manogaran, G. (2019). Efficient traceability systems of steel products using blockchain-based industrial Internet of Things. IEEE Transactions on Industrial Informatics, 16(9), 6004-6012.

Carullo, A., Corbellini, S., Parvis, M., \& Vallan, A. (2008). A wireless sensor network for cold-chain monitoring. IEEE Transactions on Instrumentation and Measurement, 58(5), $1405-1411$.

Cohen, J. (1992). A power primer. Psychological Bulletin, 112(1), 155.

Cohen, R., Allaby, C., Cumbaa, C., Fitzgerald, M., Ho, K., Hui, B., et al. (1998). What is initiative? User Modeling and UserAdapted Interaction, 8(3-4), 171-214.

Cole, R., Stevenson, M., \& Aitken, J. (2019). Blockchain technology: Implications for operations and supply chain management. Supply Chain Management: An International Journal, 24(4), 469-483.

Collier, N., Fishwick, F., \& Floyd, S. W. (2004). Managerial involvement and perceptions of strategy process. Long Range Planning, 37(1), 67-83.

Capricorn Indonesia Consult, P. (2019). A cold chain study of Indonesia. In E. Kusano (Ed.), The cold chain for agri-food products in ASEAN (pp. 101-147). Jakarta: ERIA Research Project Report FY2018 ed.

Duclos, L. K., Vokurka, R. J., \& Lummus, R. R. (2003). A conceptual model of supply chain flexibility. Industrial Management \& Data Systems, 103(6), 446-456.

Fiddes, L. K., \& Yan, N. (2013). RFID tags for wireless electrochemical detection of volatile chemicals. Sensors and Actuators B: Chemical, 186, 817-823.

Foraker, R. E., Lai, A. M., Kannampallil, T. G., Woeltje, K. F., Trolard, A. M., \& Payne, P. R. (2020). Transmission dynamics: Data sharing in the COVID-19 era. Learning Health Systems, e10235.

Fornell, C., \& Larcker, D. F. (1981). Evaluating structural equation models with unobservable variables and measurement error. Journal of Marketing Research, 18(1), 39-50.

Galbreath, J. (2006). Corporate social responsibility strategy: strategic options, global considerations. Corporate Governance: The international journal of business in society, 6(2), 175-187.

Ganyani, T., Kremer, C., Chen, D., Torneri, A., Faes, C., Wallinga, J., \& Hens, N. (2020). Estimating the generation interval for coronavirus disease (COVID-19) based on symptom onset data, March 2020. Eurosurveillance, 25(17), 2000257.

Garg, L., Chukwu, E., Nasser, N., Chakraborty, C., \& Garg, G. (2020). Anonymity preserving IoT-based COVID-19 and other infectious disease contact tracing model. IEEE Access, 8, $159402-159414$. 
Ghozali, I. (2008). Structural equation modeling: Metode alternatif dengan partial least square (pls): Badan Penerbit Universitas Diponegoro.

Hair, J. F., Anderson, R. E., Babin, B. J., \& Black, W. C. (2010). Multivariate data analysis: A global perspective (Vol. 7): Upper Saddle River, NJ: Pearson.

Hair, J. F., Henseler, J., Dijkstra, T. K., \& Sarstedt, M. (2014). Common beliefs and reality about partial least squares: comments on Rönkkö and Evermann.

Hair Jr, J. F., Hult, G. T. M., Ringle, C., \& Sarstedt, M. (2016). A primer on partial least squares structural equation modeling $(P L S-S E M)$ : Sage publications.

Hair, J. F., Ringle, C. M., \& Sarstedt, M. (2011). PLS-SEM: Indeed a silver bullet. Journal of Marketing Theory and Practice, 19(2), $139-152$.

Hair, J. F., Risher, J. J., Sarstedt, M., \& Ringle, C. M. (2019). When to use and how to report the results of PLS-SEM. European Business Review, 31(1), 2-24.

Han, J., Zhang, X., He, S., \& Jia, P. (2021). Can the coronavirus disease be transmitted from food? A review of evidence, risks, policies and knowledge gaps. Environmental Chemistry Letters, 19(1), 5-16.

Hart, P., \& Saunders, C. (1997). Power and trust: Critical factors in the adoption and use of electronic data interchange. Organization Science, 8(1), 23-42.

Hill, C. A., \& Scudder, G. D. (2002). The use of electronic data interchange for supply chain coordination in the food industry. Journal of Operations Management, 20(4), 375-387.

Ho, H. J., Zhang, Z. X., Huang, Z., Aung, A. H., Lim, W.-Y., \& Chow, A. (2020). Use of a real-time locating system for contact tracing of health care workers during the COVID-19 pandemic at an infectious disease center in Singapore: Validation study. Journal of Medical Internet Research, 22(5), e19437.

Hobbs, J. E. (2020). Food supply chains during the COVID-19 pandemic. Canadian Journal of Agricultural Economics/revue Canadienne D'agroeconomie, 68(2), 171-176.

Hu, J., Zhang, X., Moga, L. M., \& Neculita, M. (2013). Modeling and implementation of the vegetable supply chain traceability system. Food Control, 30(1), 341-353.

Hu, L.-T., \& Bentler, P. M. (1998). Fit indices in covariance structure modeling: Sensitivity to underparameterized model misspecification. Psychological Methods, 3(4), 424.

Huber, G. P. (2011). Organizations: Theory, design, future APA handbook of industrial and organizational psychology, Vol 1: Building and developing the organization. (pp. 117-160): American Psychological Association.

Hulland, J. (1999). Use of partial least squares (PLS) in strategic management research: A review of four recent studies. Strategic Management Journal, 20(2), 195-204.

ILFA. (2020). Asosiasi Logistik dan Forwarder Indonesia., from http://www.ilfa.or.id/

Jedermann, R., Ruiz-Garcia, L., \& Lang, W. (2009). Spatial temperature profiling by semi-passive RFID loggers for perishable food transportation. Computers and Electronics in Agriculture, 65(2), 145-154.

Joshi, R., Banwet, D., \& Shankar, R. (2011). A Delphi-AHP-TOPSIS based benchmarking framework for performance improvement of a cold chain. Expert Systems with Applications, 38(8), 10170-10182.

Joshi, R., Banwet, D., Shankar, R., \& Gandhi, J. (2012). Performance improvement of cold chain in an emerging economy. Production Planning \& Control, 23(10-11), 817-836.

Kärkkäinen, M. (2003). Increasing efficiency in the supply chain for short shelf life goods using RFID tagging. International Journal of Retail \& Distribution Management, 31(10), 529-536.
Khanagha, S., Volberda, H., \& Oshri, I. (2017). Customer co-creation and exploration of emerging technologies: The mediating role of managerial attention and initiatives. Long Range Planning, $50(2), 221-242$.

Khoobiyan, M., Pooya, A., Tavakkoli, A., \& Rahimnia, F. (2017). Taxonomy of manufacturing flexibility at manufacturing companies using imperialist competitive algorithms, support vector machines and hierarchical cluster analysis. Engineering, Technology \& Applied Science Research, 7(2), 1559-1566.

Kim, C., \& Shin, K. (2019). A study on the measurement method of cold chain service quality using smart contract of Blockchain. The Journal of Society for e-Business Studies, 24(3), 1-18.

Konsynski, B. R. (1993). Strategic control in the extended enterprise. IBM Systems Journal, 32(1), 111-142.

Kumar, S., Luthra, S., \& Haleem, A. (2013). Customer involvement in greening the supply chain: An interpretive structural modeling methodology. Journal of Industrial Engineering International, 9(1), 1-13.

Kuo, J.-C., \& Chen, M.-C. (2010). Developing an advanced multitemperature joint distribution system for the food cold chain. Food Control, 21(4), 559-566.

Lau, R. S. M. (1996). Strategic flexibility: A new reality for worldclass manufacturing. SAM Advanced Management Journal, 61(2), 11.

Lewis, S. G., \& Boyle, M. (2017). The expanding role of traceability in seafood: Tools and key initiatives. Journal of Food Science, 82(S1), A13-A21.

Liao, P.-A., Chang, H.-H., \& Chang, C.-Y. (2011). Why is the food traceability system unsuccessful in Taiwan? Empirical evidence from a national survey of fruit and vegetable farmers. Food Policy, 36(5), 686-693.

Marbouh, D., Abbasi, T., Maasmi, F., Omar, I. A., Debe, M. S., Salah, K., et al. (2020). Blockchain for COVID-19: Review, opportunities, and a trusted tracking system. Arabian Journal for Science and Engineering, 45(12), 9895-9911.

Martínez-Jurado, P. J., \& Moyano-Fuentes, J. (2014). Lean management, supply chain management and sustainability: A literature review. Journal of Cleaner Production, 85, 134-150.

Masudin, I., Aprilia, G. D., Nugraha, A., \& Restuputri, D. P. (2021a). Impact of E-procurement adoption on company performance: Evidence from Indonesian manufacturing industry. Logistics, $5(1), 16$

Masudin, I., Lau, E., Safitri, N. T., Restuputri, D. P., \& Handayani, D. I. (2021b). The impact of the traceability of the information systems on humanitarian logistics performance: Case study of Indonesian relief logistics services. Cogent Business \& Management, 8(1), 1906052.

Masudin, I., \& Safitri, N. T. (2020). Food cold chain in indonesia during the Covid-19 pandemic: A current situation and mitigation. Jurnal Rekayasa Sistem Industri, 9(2), 99-106.

Masudin, I., Wastono, T., \& Zulfikarijah, F. (2018). The effect of managerial intention and initiative on green supply chain management adoption in Indonesian manufacturing performance. Cogent Business \& Management, 5(1), 1485212.

Mc Carthy, U., Uysal, I., Badia-Melis, R., Mercier, S., O’Donnell, C., \& Ktenioudaki, A. (2018). Global food security-Issues, challenges and technological solutions. Trends in Food Science \& Technology, 77, 11-20.

Mercier, S., Villeneuve, S., Mondor, M., \& Uysal, I. (2017). Timetemperature management along the food cold chain: A review of recent developments. Comprehensive Reviews in Food Science and Food Safety, 16(4), 647-667.

Montanari, R. (2008). Cold chain tracking: A managerial perspective. Trends in Food Science \& Technology, 19(8), 425-431. 
Musa, A., \& Dabo, A. A. A. (2016) A Review of RFID in Supply Chain Management: 2000-2015, Global Journal of Flexible Systems Management, 17(2), 189-228.

Nicola, M., Alsafi, Z., Sohrabi, C., Kerwan, A., Al-Jabir, A., Iosifidis, C., et al. (2020). The socio-economic implications of the coronavirus and COVID-19 pandemic: A review. International Journal of Surgery, 78, 185-193.

Nunnally, J. C. (1994). Psychometric theory 3E: Tata McGraw-hill education.

Nur, I., \& Supomo, B. (2002). Metodologi Penelitian Bisnis untuk Akuntansi dan Manajemen. Edisi Kedua. BPEE.

Onoda, H. (2020). Smart approaches to waste management for postCOVID-19 smart cities in Japan. IET Smart Cities, 2(2), 89-94.

Óskarsdóttir, K., \& Oddsson, G. V. (2019). Towards a decision support framework for technologies used in cold supply chain traceability. Journal of Food Engineering, 240, 153-159.

Otoom, M., Otoum, N., Alzubaidi, M. A., Etoom, Y., \& Banihani, R. (2020). An IoT-based framework for early identification and monitoring of COVID-19 cases. Biomedical Signal Processing and Control, 62, 102149.

Pal, A., \& Kant, K. (2019). Using blockchain for provenance and traceability in Internet of things-integrated food logistics. Computer, 52(12), 94-98.

Paramita, W., Rostiani, R., Winahjoe, S., Wibowo, A., Virgosita, R., \& Audita, H. (2021) Explaining the voluntary compliance to COVID-19 measures: An extrapolation on the gender perspective. Global Journal of Flexible Systems Management, 22(Suppl 1), S1-S18.

Patil, M., \& Suresh, M. (2019) Modelling the enablers of workforce agility in IoT projects: A TISM approach, Global Journal of Flexible Systems Management, 20(2), 157-175.

Paul, S. K., \& Chowdhury, P. (2020). Strategies for managing the impacts of disruptions during COVID-19: an example of toilet paper. Global Journal of Flexible Systems Management, 21(3), 283-293.

Peterson, R. A., \& Kim, Y. (2013). On the relationship between coefficient alpha and composite reliability. Journal of Applied Psychology, 98(1), 194.

Plumier, B. M., \& Maier, D. E. (2018). Sensitivity analysis of a fumigant movement and loss model for bulk stored grain to predict effects of environmental conditions and operational variables on fumigation efficacy. Journal of Stored Products Research, 78, 18-26.

Pujihastuti, I. (2010). Prinsip penulisan kuesioner penelitian. CEFARS: Jurnal Agribisnis dan Pengembangan Wilayah, 2(1), 43-56.

Rajakumar, G., Kumar, T. A., Samuel, T., \& Kumaran, E. M. (2018). Iot based milk monitoring system for detection of milk adulteration. International Journal of Pure and Applied Mathematics, 118(9), 21-32.

Rediers, H., Claes, M., Peeters, L., \& Willems, K. A. (2009). Evaluation of the cold chain of fresh-cut endive from farmer to plate. Postharvest Biology and Technology, 51(2), 257-262.

Restuputri, D. P., Indriani, T. R., \& Masudin, I. (2021). The effect of logistic service quality on customer satisfaction and loyalty using Kansei engineering during the COVID-19 pandemic. Cogent Business \& Management, 8(1), 1906492.

Restuputri, D. P., Masudin, I., \& Sari, C. P. (2020). Customers perception on logistics service quality using Kansei engineering: Empirical evidence from indonesian logistics providers. Cogent Business \& Management, 7(1), 1751021.

Reuter, C., Goebel, P., \& Foerstl, K. (2012). The impact of stakeholder orientation on sustainability and cost prevalence in supplier selection decisions. Journal of Purchasing and Supply Management, 18(4), 270-281.
Rizou, M., Galanakis, I. M., Aldawoud, T. M., \& Galanakis, C. M. (2020). Safety of foods, food supply chain and environment within the COVID-19 pandemic. Trends in Food Science \& Technology, 102, 293-299.

Rowley, J., \& Slack, F. (2004). Conducting a literature review. Management Research News, 27(6), 31-39.

Ruiz-Garcia, L., Barreiro, P., \& Robla, J. (2008). Performance of ZigBee-based wireless sensor nodes for real-time monitoring of fruit logistics. Journal of Food Engineering, 87(3), 405-415.

Ruiz-Garcia, L., Barreiro, P., Robla, J. I., \& Lunadei, L. (2010). Testing ZigBee motes for monitoring refrigerated vegetable transportation under real conditions. Sensors, 10(5), 4968-4982.

Sahin, E., Dallery, Y., \& Gershwin, S. (2002). Performance evaluation of a traceability system. An application to the radio frequency identification technology. Paper presented at the IEEE International Conference on Systems, Man and Cybernetics.

Sarkis, J., Cohen, M. J., Dewick, P., \& Schröder, P. (2020). A brave new world: Lessons from the COVID-19 pandemic for transitioning to sustainable supply and production. Resources, Conservation, and Recycling, 159, 104894.

Scala, S., \& McGrath, R., Jr. (1993). Advantages and disadvantages of electronic data interchange an industry perspective. Information \& Management, 25(2), 85-91.

Schober, P., Boer, C., \& Schwarte, L. A. (2018). Correlation coefficients: Appropriate use and interpretation. Anesthesia \& Analgesia, 126(5), 1763-1768.

Shabani, A., Torabipourv, S. M. R., \& Saen, R. F. (2015). A new super-efficiency dual-role FDH procedure: An application in dairy cold chain for vehicle selection. International Journal of Shipping and Transport Logistics, 7(4), 426-456.

Sharma, S., \& Pai, S. S. (2015). Analysis of operating effectiveness of a cold chain model using Bayesian networks. Business Process Management Journal, 21(4), 722-742.

Shashi, S., Cerchione, R., Singh, R., Centobelli, P., \& Shabani, A. (2018). Food cold chain management. The International Journal of Logistics Management, 29(3), 792-821.

Shukor, A. A. A., Newaz, M. S., Rahman, M. K., \& Taha, A. Z. (2020). Supply chain integration and its impact on supply chain agility and organizational flexibility in manufacturing firms. International Journal of Emerging Markets, https://doi.org/10. 1108/IJOEM-04-2020-0418.

Sousa, R., Yeung, A. C., \& Cheng, T. (2008). Customer heterogeneity in operational e-service design attributes. International Journal of Operations \& Production Management, 28(7), 592-614.

Streiner, D. L. (2003). Starting at the beginning: An introduction to coefficient alpha and internal consistency. Journal of Personality Assessment, 80(1), 99-103.

Sugiyono, P. (2013). Statistik untuk Penelitian. CV. Alvabeta Bandung.

Tam, L. T., Ho, H. X., Nguyen, D. P., Elias, A., \& Le, A. N. H. (2021). Receptivity of Governmental Communication and Its Effectiveness During COVID-19 Pandemic Emergency in Vietnam: A Qualitative Study. Global Journal of Flexible Systems Management, 22(Suppl 1), S45-S64.

Tenenhaus, M., Vinzi, V. E., Chatelin, Y.-M., \& Lauro, C. (2005). PLS path modeling. Computational Statistics \& Data Analysis, 48(1), 159-205.

Thompson, C. B. (2009). Descriptive data analysis. Air Medical Journal, 28(2), 56-59.

Tian, F. (2016). An agri-food supply chain traceability system for China based on RFID \& blockchain technology. Paper presented at the 2016 13th international conference on service systems and service management (ICSSSM).

Tobing, B. (2015). Food supply chain., from https://supplychainindo nesia.com/wp-content/files/Rantai_Pasok_Pangan1.pdf 
Tsang, Y. P., Choy, K. L., Wu, C.-H., Ho, G. T., Lam, C. H., \& Koo, P. (2018). An Internet of Things (IoT)-based risk monitoring system for managing cold supply chain risks. Industrial Management \& Data Systems, 118(7), 1432-1462.

Ufua, D. E., Osabuohien, E., Ogbari, M. E., Falola, H. O., Okoh, E. E., \& Lakhani, A. (2021) Re-Strategising government palliative support systems in tackling the challenges of COVID-19 lockdown in Lagos State, Nigeria. Global Journal of Flexible Systems Management, 22(Suppl 1), S19-S32.

van der Weerdt, N. P., Volberda, H. W., Verwaal, E., \& Stienstra, M. (2012). Organizing for flexibility: addressing dynamic capabilities and organization design Collaborative Communities of firms (pp. 105-125). Springer.

Vergara, I. G. P., Gómez, M. C. L., Martínez, I. L., \& Hernández, J. V. (2021). Strategies for the preservation of service levels in the inventory management during COVID-19: A case study in company of biosafety products. Global Journal of Flexible Systems Management, 22(Suppl 1), S65-S80.

Volberda, H. W. (1996). Toward the flexible form: How to remain vital in hypercompetitive environments. Organization Science, 7(4), 359-374.

Volberda, H. W. (2003). Strategic flexibility creating dynamic competitive advantages. The Oxford handbook of strategy.

Walton, S. V., \& Marucheck, A. S. (1997). The relationship between EDI and supplier reliability. International Journal of Purchasing and Materials Management, 33(2), 30-35.

Wang, X., Li, D., \& O'brien, C. (2009). Optimisation of traceability and operations planning: An integrated model for perishable food production. International Journal of Production Research, 47(11), 2865-2886.

Webster, J. (1995). Networks of collaboration or conflict? Electronic data interchange and power in the supply chain. The Journal of Strategic Information Systems, 4(1), 31-42.

Wiersinga, W. J., Rhodes, A., Cheng, A. C., Peacock, S. J., \& Prescott, H. C. (2020). Pathophysiology, transmission, diagnosis, and treatment of coronavirus disease 2019 (COVID-19): A review. JAMA, 324(8), 782-793.

Winter, S. G. (2003). Understanding dynamic capabilities. Strategic Management Journal, 24(10), 991-995.

Wu, J.-Y., \& Hsiao, H.-I. (2020). Food quality and safety risk diagnosis in the food cold chain through failure mode and effect analysis. Food Control, 120, 107501.

Zollo, M., \& Winter, S. G. (2002). Deliberate learning and the evolution of dynamic capabilities. Organization Science, 13(3), 339-351.

Zou, Z., Chen, Q., Uysal, I., \& Zheng, L. (2014). Radio frequency identification enabled wireless sensing for intelligent food logistics. Philosophical Transactions of the Royal Society A: Mathematical, Physical and Engineering Sciences, 372(2017), 20130313.

\section{Key Questions}

1. What are the important elements that affect supply chain agility and organizational flexibility?

2. What are the factors that affect the performance of the food cold chain?

3. How do managerial initiatives moderate the relationship between traceability systems and food cold chain performance?
Publisher's Note Springer Nature remains neutral with regard to jurisdictional claims in published maps and institutional affiliations.

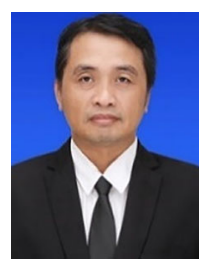

Ilyas Masudin is a professor of logistics and supply chain at Industrial Engineering department, University of Muhammadiyah Malang, Indonesia. He holds a Ph.D. in Logistics from RMIT University, Australia. His research interests include logistics optimization, supply chain management, multi-criteria decision-making and operations management.

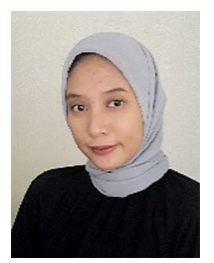

Anggi Ramadhani is a researcher in Industrial Engineering department, University of Muhammadiyah Malang, Indonesia. Her research interests are industrial system optimization, system modelling and operations management.

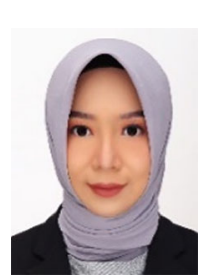

Dian Palupi Restuputri is a senior lecturer and researcher in Industrial Engineering department at the University of Muhammadiyah Malang. Her research interests are in the area of ergonomics and human factor engineering. She received his bachelor's degree in Industrial Engineering from the Diponegoro University, Indonesia (2007). She holds a master's degree in Industrial Engineering from Institute of Technology Bandung, Indonesia (2012).

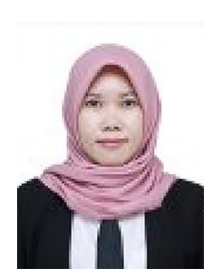

Ikhlasul Amallynda is a lecturer at Industrial Engineering department, University of Muhammadiyah Malang, Indonesia. Her research interests are system modeling and operations management. 